\title{
Measures to Remove Geothermal Energy Barriers in the European Union
}

\author{
Antonio Colmenar-Santos ${ }^{1}{ }^{\circledR}$, Elisabet Palomo-Torrejón ${ }^{1}{ }^{\circledR}$, Enrique Rosales-Asensio ${ }^{2}$ and \\ David Borge-Diez ${ }^{2, *(1)}$
}

1 Departamento de Ingeniería Eléctrica, Electrónica, Control, Telemática y Química Aplicada a la Ingeniería, UNED, Juan del Rosal, 12 Ciudad Universitaria, 28040 Madrid, Spain; acolmenar@ieec.uned.es (A.C.-S.); epalomo27@alumno.uned.es (E.P.-T.)

2 Departamento de Ingeniería Eléctrica y de Sistemas y Automática, Universidad de León, Escuela de Ingenierías Industrial e Informática Campus de Vegazana, s/n 24071 León, Spain; erosalea@ull.edu.es

* Correspondence: david.borge@unileon.es; Tel.: +349-872-952-66

Received: 20 September 2018; Accepted: 11 November 2018; Published: 18 November 2018

\begin{abstract}
This article examines the main market barriers that hamper the introduction of geothermal energy at local, national, and European levels as well as the necessary steps that need to be taken to eradicate them, thus contributing to the general use of this renewable source of energy. The novelty of this study lies in the detailed description of four different scenarios: the European Union (EU), Spain, the Canary Islands, and the agricultural sector for the three types of geothermal energies and their uses: Low-enthalpy or thermal uses, high-enthalpy or electrical uses and renewable energy mix. The results are expected to differ in terms of level of introduction, barriers, and measures to be taken. We have selected Spain within the European context due to its meagre $0.1 \%$ geothermal market share in primary demand for renewable energy, and the Canary Islands in particular, given its insular nature. We have likewise picked the agricultural sector due to its underdevelopment as far as renewable energies are concerned, including geothermal energy.
\end{abstract}

Keywords: geothermal energy; barriers; analysis; energy efficiency; European Union

\section{Introduction}

Various indicators show that there is still a commitment to subsidize fossil fuels at the expense of renewable energy and energy efficiency projects, as shown in the results of the Madrid Summit [1-4]. In the case of micro grids, the lack of specific regulation and the fact that it is still a budding technology renders it a rather costly option as a source of energy, not so much because of technical barriers-even though this aspect could be improved but due to regulatory, legislative, and economic vacuums [5].

Given today's increasing demand for energy, a response that deals with a sustainable energy framework is essential. Many articles raise the question of identifying the actual barriers to the introduction of renewable energies all over the world. These barriers, however, are expected to differ according to different types of renewable energy, environment, and sector of activity. As far as geothermal energy is concerned, despite its all-year-round availability and its independence from external climatological factors, it is scarcely used both on its own and as an energy mix. Hence, there is a need to elaborate more specific studies on the barriers that affect it and the actions that need to be taken to take full advantage of its potential.

One of the main challenges that geothermal energy faces, both for thermal and for electrical uses, is the ignorance of the general public [6]. In the case of geothermal power generation, the absence of a favorable regulatory framework results in the complete lack of power plants in Spain despite isolated entrepreneurial endeavors to establish them [6]. On the other hand, and excluding the barrier of the 
initial investment and the regulations required of high-enthalpy geothermal projects, we would like to point out that there has been certain improvements regarding knowledge and research of the subsoil in areas considered potentially favorable in Spain, besides, a greater involvement in the development of this sector will lead to an increase in projects of this kind [6]. In the case of low-enthalpy geothermal energy, non-compliance in recent years derives from the fact that it requires a higher initial investment than that of a conventional plant, and the climate of economic downturn over the last decade has not helped. However, in the current, more favorable, context in Spain, there are numerous private initiatives being carried out, especially as far as building renovations are concerned [6].

Considering the substantial technical barriers in the case of micro grids, an implementation of changes in meters, safety, ground and linking with the existing electricity grid as well as management of production and consumption and aggregation of new energy sources are seen as necessary at a local level [5]. As far as geothermal energy in Spain is concerned, working towards not only the introduction of regulatory actions but also on demonstration programs, knowledge management on geothermal potentiality, technology development programs aimed at reducing production costs, and increasing efficiency and developing a training and certification model are viewed as a must [6].

There are numerous references that confirm that the main disadvantage of using renewable energies stems from adverse climatological factors-rain, sun, wind $[7,8]$. By contrast, the main advantage of geothermal energy, both in its isolated form and in the form of an energy mix lies in its complete year-round availability and the fact that it does not need to oversize the capacity of the system to compensate for lack of energy. Furthermore, solar and wind energy have a negative impact on the landscape and farming land. This is not the case of geothermal systems due to its concealed nature $[7,8]$. Many articles mention the need to implement renewable energies and improve energy efficiency in remote areas, such as islands not only from an environmental point of view $\left(\mathrm{CO}_{2}\right.$ and greenhouse gases emissions reduction) but also because they have proven to be more profitable than conventional polluting energy sources, where part of the cost of the bill is often subsidized $[1,2,7,8]$.

It is worth noting that the contribution of renewable resources to the sustainability of energy is ever more relevant in remote and insular areas [9]. Therefore, the Canary Islands were handpicked for this study. One of the most recurrent topics in a variety of articles is the importance of implementing renewable energies at a local level. Unfortunately, European policies show little support on this matter [10]. There are examples in insular areas, such as the Spanish island of Menorca, of potential energy self-sufficiency through photovoltaic solar energy, where a geothermal study would be desirable [2]. In other European islands like Mykonos in Greece, there have been studies on solar and wind energy production [7]. They are all similar case studies: tourist islands with high electricity and water consumption in which fuel produced electricity is shared with agriculture and industry $[2,8]$. Some studies propose the desalination of sea water through renewable energies in insular areas, again making use of solar and wind resources [8] but with a need to oversize installations in the absence of such resources. An interesting option would be installing a geothermal line that could guarantee year-round energy resources without needing to oversize the systems. In fact, in some studios, the use of geothermal energy for thermal desalination can be justified only in the presence of cheap geothermal reservoirs or in decentralized applications that focus on small-scale water supplies in coastal regions, provided that society is able and willing to pay for desalting [11].

The proposal of desalination plants using energy mix is an interesting option for coastal, insular, or desert areas where water resources are scarce since it would benefit both drinking water consumption and water destined to irrigation areas, thus helping to develop the agricultural sector in a sustainable way. Besides, the coupling solar-geothermal in regions with a lot of radiation is a very interesting option for cogeneration plant based on an Organic Rankine Cycle (ORC), powered by a medium-enthalpy geothermal resource and a Parabolic Trough Collector solar field [12]. Some studies show the importance of land management (planning, agriculture, conservation) and geographic studies to implement energy strategies [13]. Geothermal energy can be put into a myriad of uses and many have already been studied, though most of them are still in pilot stage-from electricity production to 
urban heating or agricultural applications, such as greenhouse and stockbreeding facilities heating, besides industrial applications through the use of underground infrastructures, heating for residential and official buildings and swimming pools, just to name a few.

Economic and environmental analysis of different District Heating systems aided by geothermal energy were analyzed in a set of buildings located in the province of León in the north of Spain. Real data comparison of the different scenarios studied revealed the most suitable option from an economic and environmental point of view was the assumption of a district heating system totally supplied by geothermal energy clearly stands out from the rest of options [14].

Most case studies around the word relate to domestic and residential uses that use geothermal heat pumps, although there are endless applications and sectors still to be developed and improved. In the agricultural sector, for example, the use of geothermal energy in Greece for fruit drying or in Iceland for cod drying are of interest [13]. In the case of Spain, studies on central heating and sanitary hot water have been carried out in Madrid, greenhouse heating in Cartagena, Murcia and in the sandy fields of Dallas in Almeria [15]. Residential examples elsewhere, like the one in Okotoks, Canada [16] or Crailsheim in Germany, are also worth noting [17], both cases consisting on the hybridization of solar thermal energy with geothermal energy through a geothermal storage. In a similar way, an innovative space-conditioning system is proposed, and a life-cycle assessment is presented for an industrial building. A ground-source heat pump system and an upstream thermal storage are analyzed to reduce the size of the geothermal installation [18].

Based on the above-mentioned references, it is reasonable to conclude that geothermal energy has an enormous potential both for small-scale projects like home heating and for greenhouse or large district heating projects with subsoil thermal energy accumulation capable of supplying thermal energy to an entire city [19].

Unfortunately, market parameters, such as acceptance from investors, regulatory framework, planning restrictions, and environmental impact, need to be addressed for this kind of technology to achieve effective development [19].

Nevertheless, specific studies exploring barriers to the introduction of geothermal energy and/or geothermal energy mix have not been found, although in some cases they are mentioned as an objective for exploration [2]. Most of the references consulted are on wind and solar energies [2,20]. There are some theoretical references in Turkey, where different types of renewable energy were contrasted with five criteria to be taken into consideration: technical, economic, political, social and environmental. According to this, geothermal energy gets the highest score [21]. Likewise, six production plants in that country are analyzed based on a series of criteria: technology and sustainability, economy, quality of life and socio-economic aspects. Here, geothermal plants rank in the third position.

There exist some investigations that focus on the main barriers and actions needed regarding the introduction of renewable energies in different uses, contexts, regions, and countries [18]. However, the novelty of this study resides in the scrutiny of barriers and steps to be taken to introduce an energy with such a strong potentiality and as little known as geothermal energy.

In other non-detailed studies on renewable energies where northern European countries (from now on N) are compared with southern European countries (from now on S), it seems like financial barriers are more significant in the latter due to, among other reasons, little tradition of financial support for this type of project from legally established cooperatives. It is also due to a lack of local or municipal initiatives aimed at electricity production, or difficulty to access credits and incentives. As far as social and cultural barriers are concerned, it seems that lack of environmental awareness in southern Europe against a history of energy activism in the $\mathrm{N}$ has enabled the creation of bioenergy towns in countries like Germany, thus contributing towards lowering barriers to the introduction of renewable energies to a greater extent than their southern counterparts [22]. Other studies show that oil prices and the initial investment needed are significant financial barriers [23]. 
In a study of a hybrid project comprising solar, geothermal and wind energies for a greenhouse in Turkey [24], initial investment as opposed to established heating systems for agriculture and buildings, appears to be the most relevant barrier".

However, this study concludes that with enough wind this system is preferable to conventional ones.

Similarly, other studies show that, in some cases, institutions contribute significantly to the energy mix and energy policies, proving that institutional quality and income resources are of great importance in the development of renewable energies in any country [25]. As far as cultural and social barriers are concerned, it is worth noting that in all cases a lack of social acceptance may be a great deterrent to the achievement of desired targets in Europe [26].

More generic studies on renewable energies [13] consider promotion as a key measure for development, along with the establishment of national regulations concerning licenses, permits, and procedures. Renewable energy strategies at the local level based on knowledge, training, and monitoring are also necessary. Some studies suggest that once the use of a technology is explained, the intention to use it increases [27]. This is directly linked to the importance of promotion as part of the effort to introduce new technologies. In articles that analyze the situation of Dutch industrial companies in terms of implementation of energy efficiency, public investment is also highlighted as a key element [27]. In Michalena and Hills' studio, security and diversification of electricity supply are mentioned as elements to take into consideration due to, on the one hand, the high dependency of fossil fuels in many regions and, on the other hand, the high cost of oil [13]. Lin and Omoju's article underlines that in the short run, oil price increase affects the development of renewables, but in the long term, financing plays an important role and therefore only adequate planning can help promote the change towards energy transition [28].

After the initial introductory section, the second section explores materials and methods and presents the methodology applied on this article for national (Spain) and European contexts, as well as focusing at a local level (the Canary Islands) and in the specific sector of agriculture. In section three, the results obtained will be examined and discussed. In the final section, we present conclusions reached as a result of the research carried out in the article. All sections are complemented with a series of Appendices A-D containing relevant extra information. Appendix A includes the forms that were sent to various experts in the field; Appendix B contains graphic information and questions asked to experts in the field; Appendix $C$ gives graphic information on the most relevant advantages stemming from implementing this kind of technology; Appendix D contains an additional questionnaire of eight closed-ended questions with graphic representations relevant to the above mentioned questionnaire.

\section{Materials and Methods}

To carry out our research, we will start by looking at barriers to entry from the point of view of the market and examine the extent to which they coincide with replies obtained in this section. For the development of the research, fifty-four experts were contacted and sent a series of questionnaires (Appendix A). Each questionnaire contained twenty questions, as elaborate and detailed as possible, about ways of finding solutions to barriers to the introduction of geothermal energy in Spain, the EU, the Canary Islands, and in the agricultural sector and taking requisite steps to eradicate them. A total of eleven replies from experts were received with a success rate of twenty percent.

The methodology used corresponds to "non-probabilistic sampling" since it is a small but representative sample well known to the researchers [29]. Validation is supported by "expert judgment" for which relevant experts in the field of geothermal energy and renewable energies in a position to give an answer to the current situation concerning barriers to the introduction of this technology in Spain, the EU and the Canary Islands were contacted for a period of three months (from October 2017 to December 2017). Questionnaire models can be found in Appendix A. The study is structured in four main blocks intended to cover each of the three technologies and the four scenarios shown in Figure 1. 

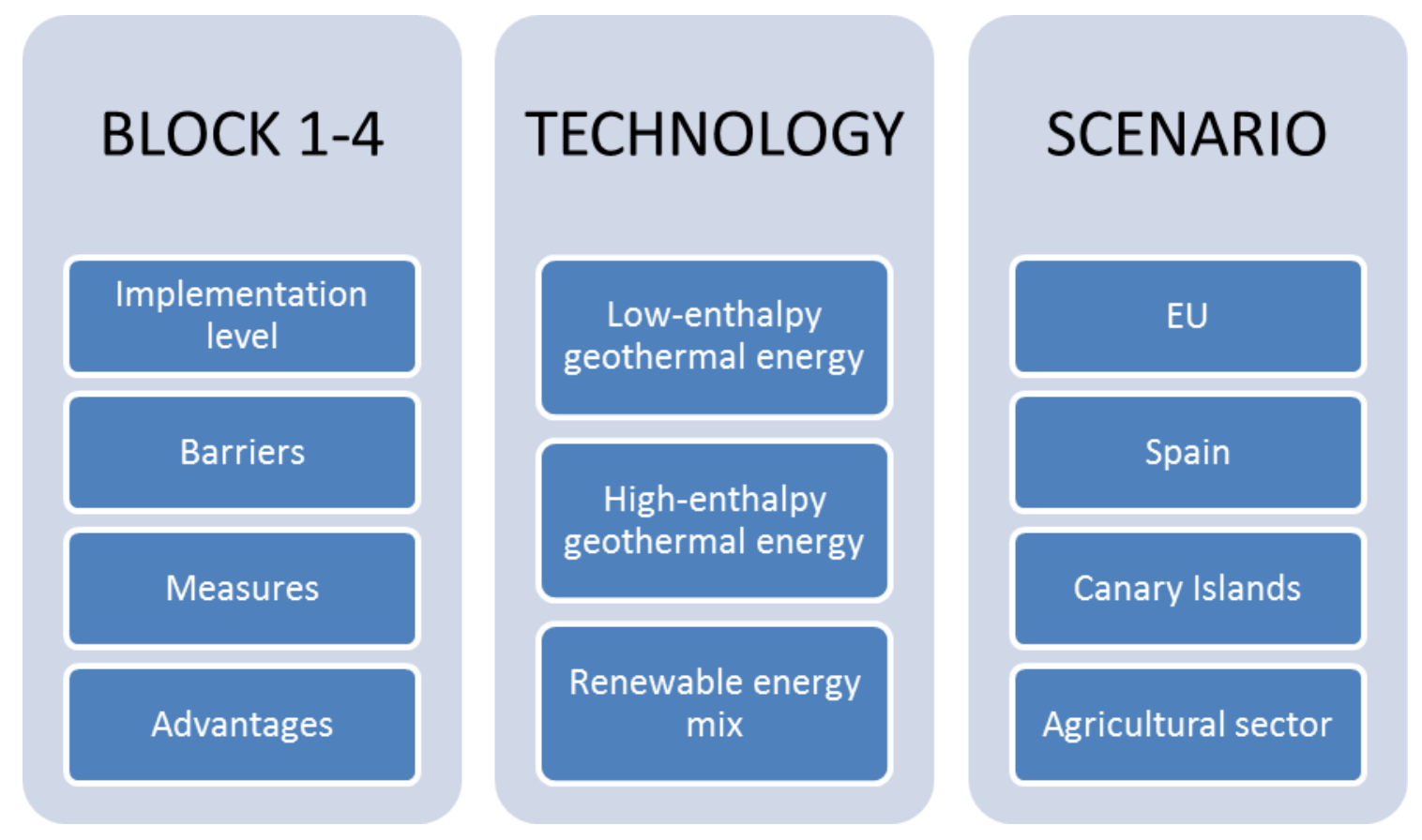

Figure 1. Representation of the blocks, technologies and scenarios studied. Source: Own elaboration.

\section{Results and Discussion}

As mentioned in the previous section, the results of this study are presented in four main blocks. They are intended to verify whether the questions formulated in the materials and methods section apply to the situation of geothermal energy in all its modalities and to the energy mix in specific locations and sector.

\subsection{Block 1: Level of Implementation}

Figures 2-4 support BLOCK 1: Level of introduction of geothermal energy in all its modalities: Low-enthalpy, high-enthalpy and even as part of renewable energy mix in Spain, the EU, the Canary Islands, and on the specific currently underdeveloped sector of agriculture. In view of the results reflected in Figure 2 regarding the level of introduction of geothermal energy, the smallest differences of opinion between Spanish and European experts can be seen in the implementation of low-enthalpy geothermal energy or thermal uses and geothermal energy in the agricultural sector.

On the other hand, the greatest differences of opinion between Europe and Spain relate to high-enthalpy geothermal energy, renewable mix, and renewable energy in the agricultural sector. The greatest difference of opinion is on potential electrical uses for geothermal energy.

In all cases for this first graph (Figure 2), the European experts evaluate a higher level of development of geothermal energy in the EU in all its facets as compared to the Spanish experts in Spain. It seems that it is not exclusive to geothermal energy, since some studies compare the situation of renewable energies in general between $\mathrm{N}$ and $\mathrm{S}$ countries in Europe and the level of involvement and acceptance is also greater in the former [21].

Other studies highlight the fact that the higher the level of development or income of a country, the more relevant the investment in renewables [6,30].

In the case of the Canary Islands as compared to the whole of Spain (Figure 3), all questions are slightly lower on the assessment scale than those on the general situation in Spain, except for the energy mix.

In view of the aforementioned, Figure 4, which includes judgement of all the experts consulted from Spain, the Canary Islands, and the European Union, is drawn up. 
In all questions asked the level of development equals 2 on a 1-5 scale, the rating is even lower on geothermal energy for electrical uses as well as geothermal energy on the agricultural sector compared to the others. In any case, from the observation of Figures 2-4 we can infer that for all questions, the level of development is around 2, meaning underdevelopment.

Without a doubt, and quoting Surtesic, "It is of the utmost importance to make great efforts to promote strong renewable technologies such as geothermal energy" [31].

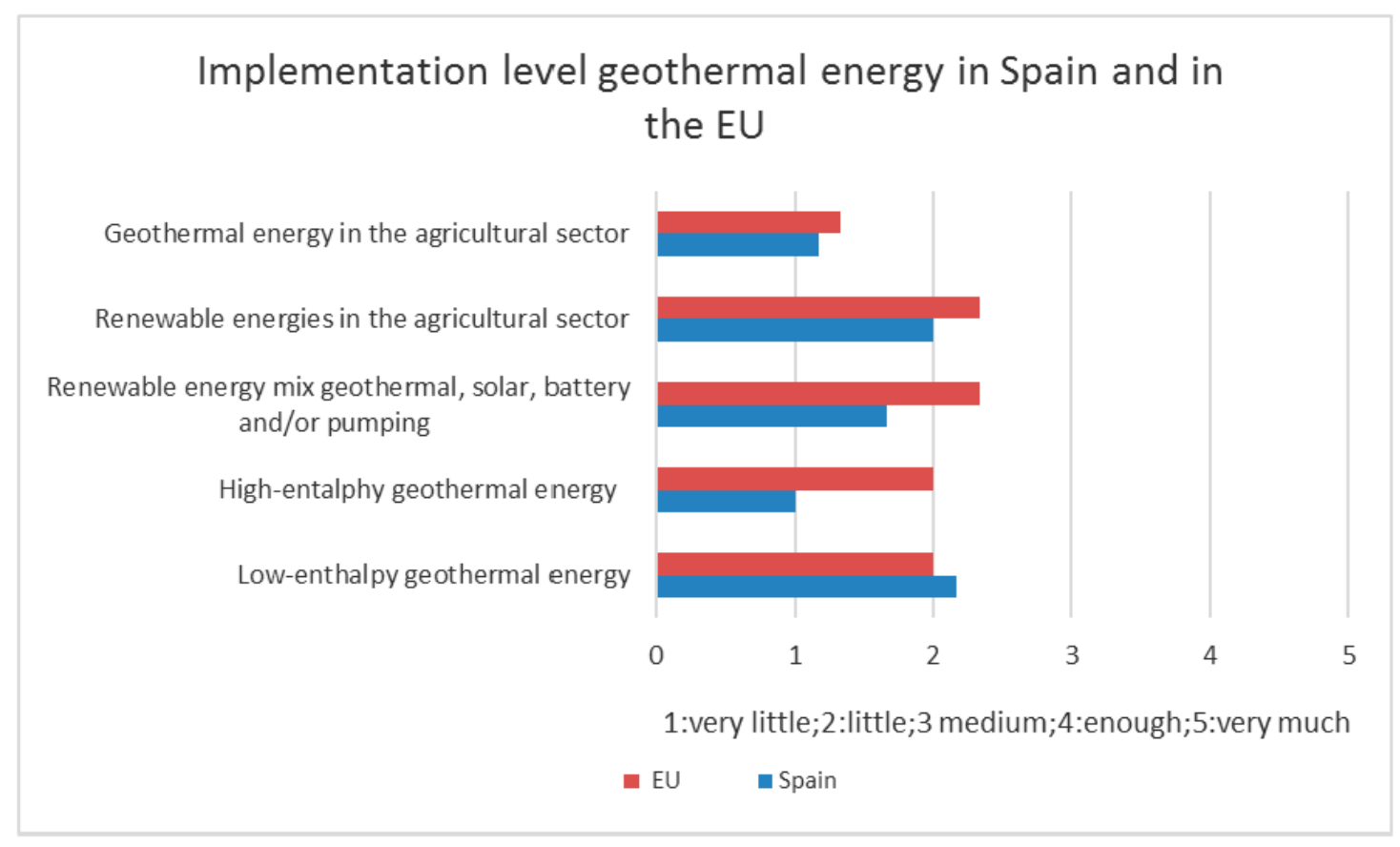

Figure 2. Comparative at the implementation level: Geothermal energy in Spain and in the EU. Source: Own elaboration.

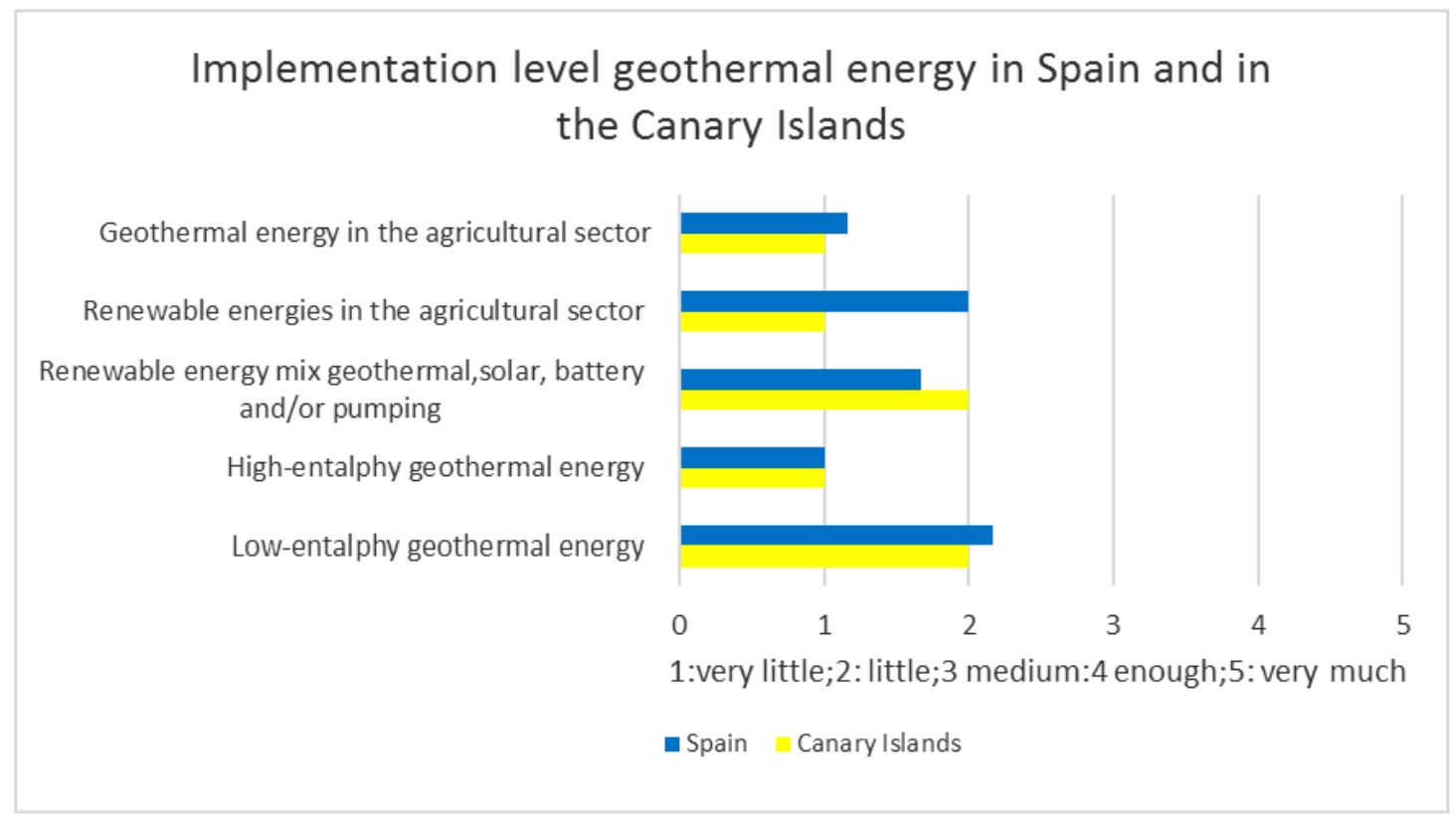

Figure 3. Comparative at the implementation level: Geothermal energy in Spain and in the Canary Islands. Source: Own elaboration. 


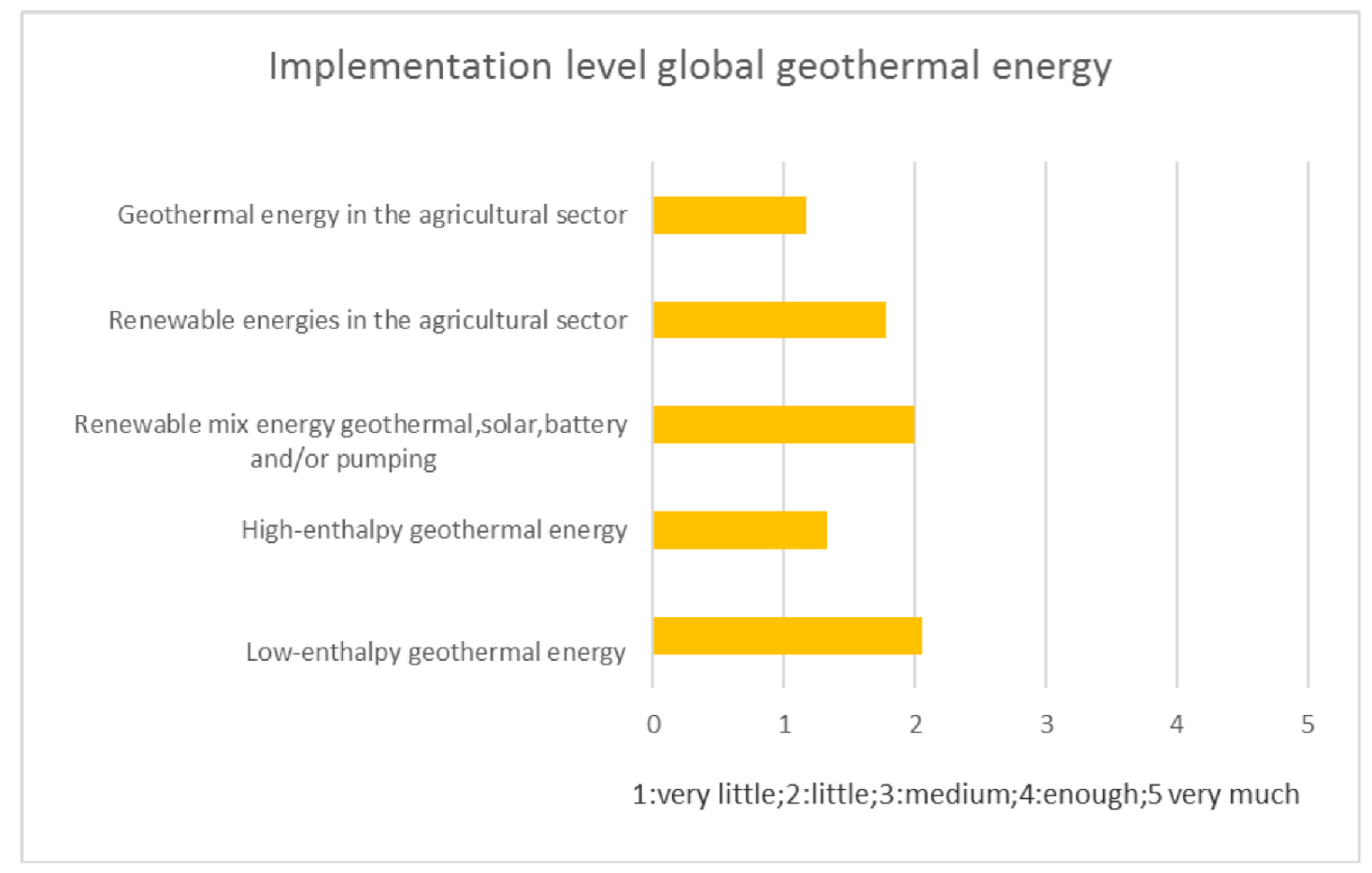

Figure 4. Comparative at the implementation level: Global geothermal energy. Source: Own elaboration.

\subsection{Block 2: Barriers}

\subsubsection{Low-Enthalpy Geothermal Energy}

As far as graphs of BLOCK 2 are concerned (Figures 5-8 on low enthalpy geothermal energy), Figure 5 shows how European experts unanimously consider economic or financial barriers for Europe, followed at a lower percentage by regulatory/institutional, technical, and cultural/social. For the Spanish experts, economic or financial barriers are also the most important, the technical type is less representative.

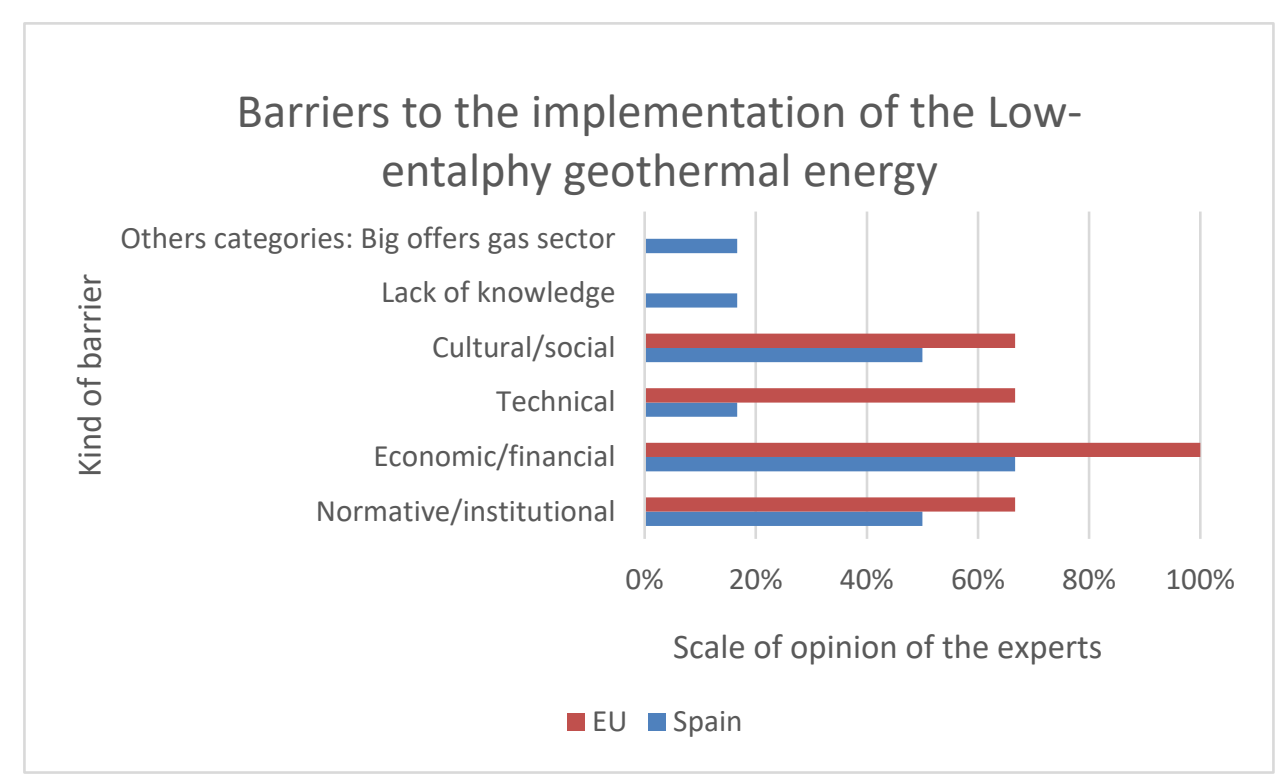

Figure 5. Barriers to the implementation of the low-enthalpy geothermal energy (comparative between Spain and the EU). Source: Own elaboration. 
On the agricultural sector (Figure 6), along with economic/financial barriers, cultural/social barriers appear to the same extent, and in the case of the Canary Islands (Figure 7) beside cultural/social stands regulatory/institutional. Considering the opinion of all the experts consulted in Spain, the EU, the Canary Islands and on the agricultural sector and after applying their specific weight on the issues here considered, we obtain Figure 8, which reveals that the main barriers are cultural/social followed by economic/financial and regulatory/institutional. Excluding the opinion of experts in the Canary Islands and in the agricultural sector, which represent the smallest of the samples, the main barriers are economic/ financial, followed by regulatory/institutional and cultural/social on equal terms.

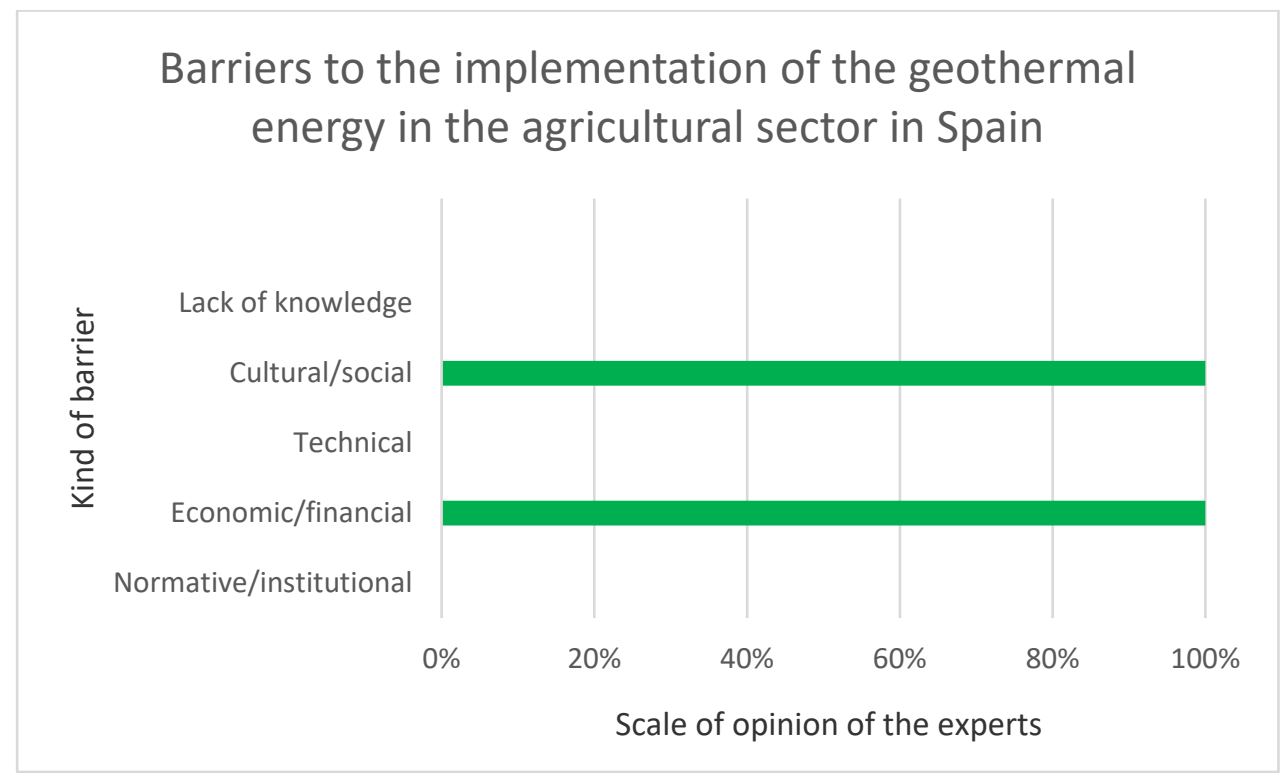

Figure 6. Barriers to the implementation of the geothermal energy in the agricultural sector in Spain Source: Own elaboration.

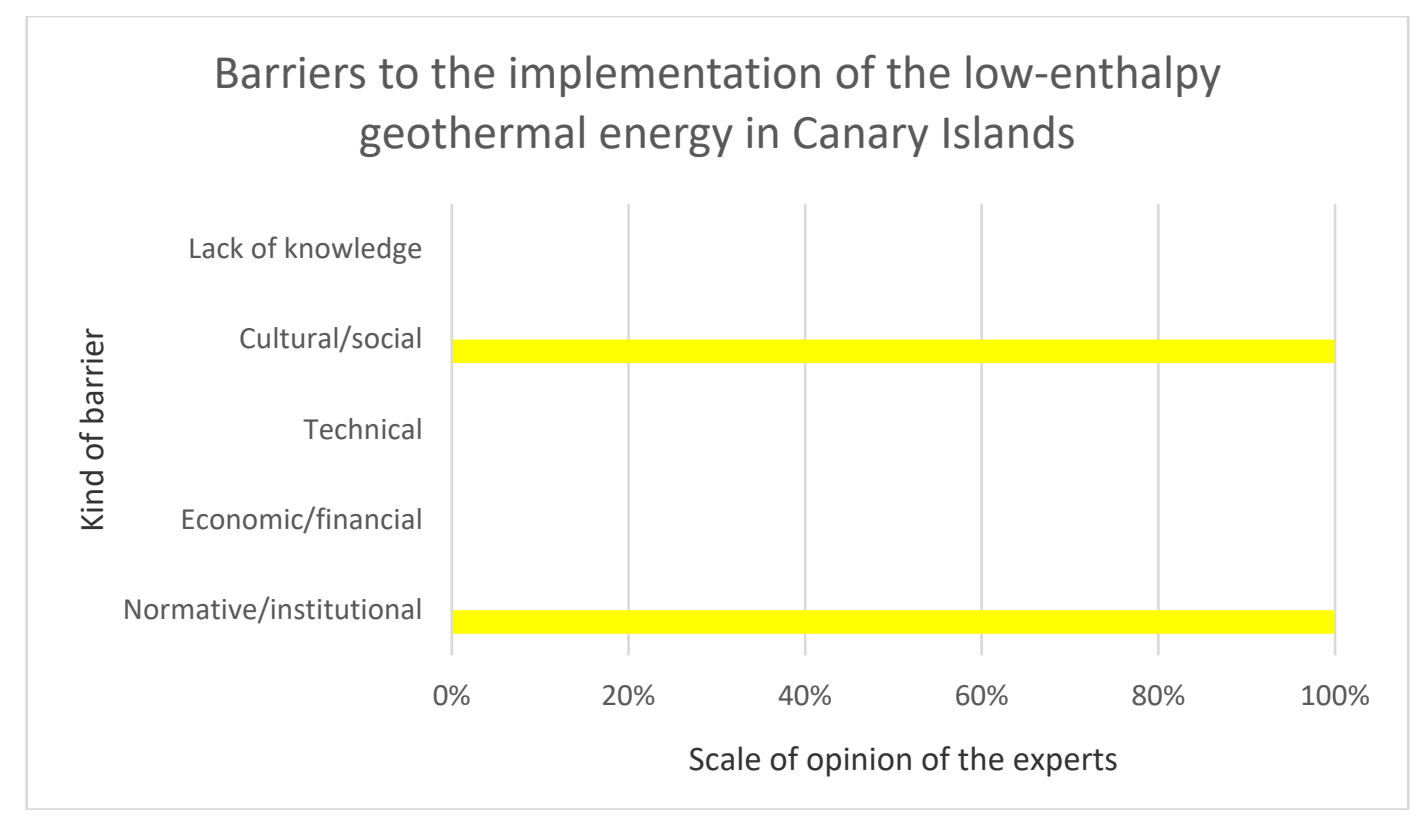

Figure 7. Barriers to the implementation of the low-enthalpy geothermal energy in the Canary Islands. Source: Own elaboration. 


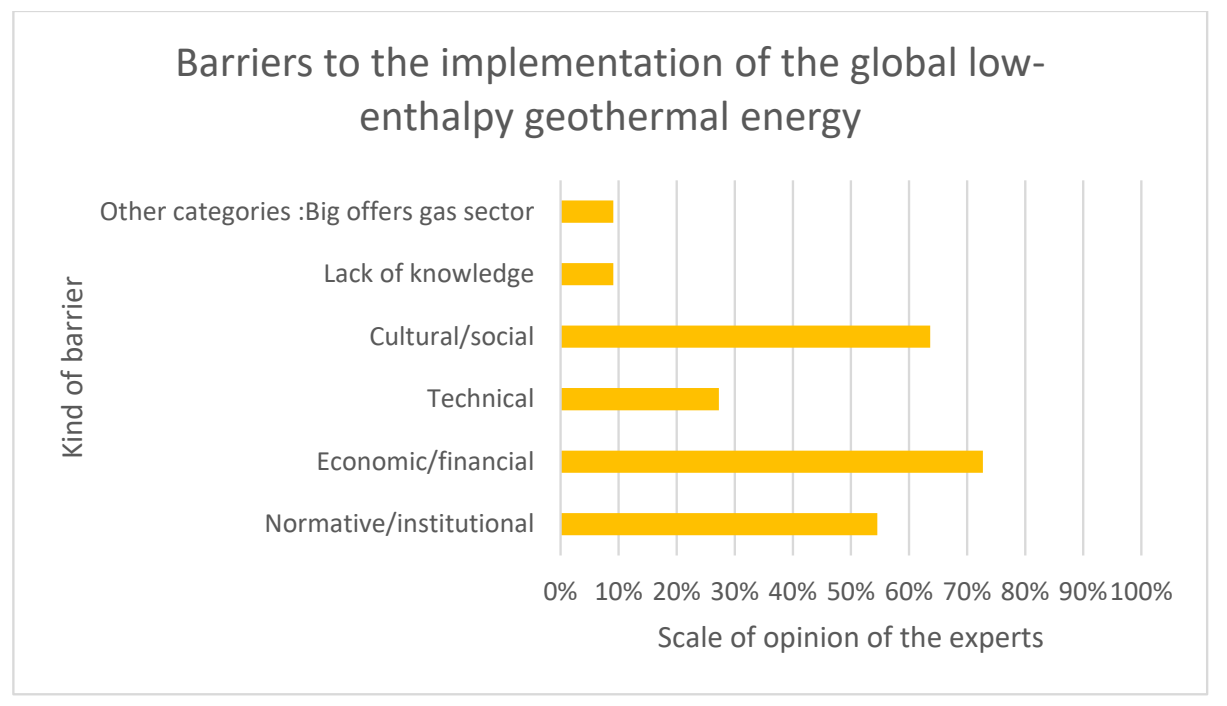

Figure 8. Barriers to the implementation of the global low-enthalpy geothermal energy. Source: Own elaboration.

\subsubsection{High-Enthalpy Geothermal Energy}

In terms of electrical uses, geothermal energy has been studied in Spain, the EU, and the Canary Islands. As far as the agricultural sector is concerned, it has only been considered as renewable energy in general and geothermal in particular without differentiating its thermal or electrical end uses or even the geothermal mix.

With reference to barriers to the introduction of high-enthalpy geothermal energy reflected on Figure 9 judgement of experts is unanimous for the situation in Spain and the EU, economic/financial being the main barriers. It is the same case of the Canary Islands (Figure 10).

On an analysis of high-enthalpy, similar to the one on low-enthalpy that takes into consideration the opinion of all the experts asked about the situation in Spain, the EU, and the Canary Islands (with their specific weight), we once again find unanimity of criteria with $100 \%$ thinking the most important barriers are economic/financial. However, in this case and unlike on low-enthalpy geothermal, the second most important barriers seem to be technical (Figure 11).

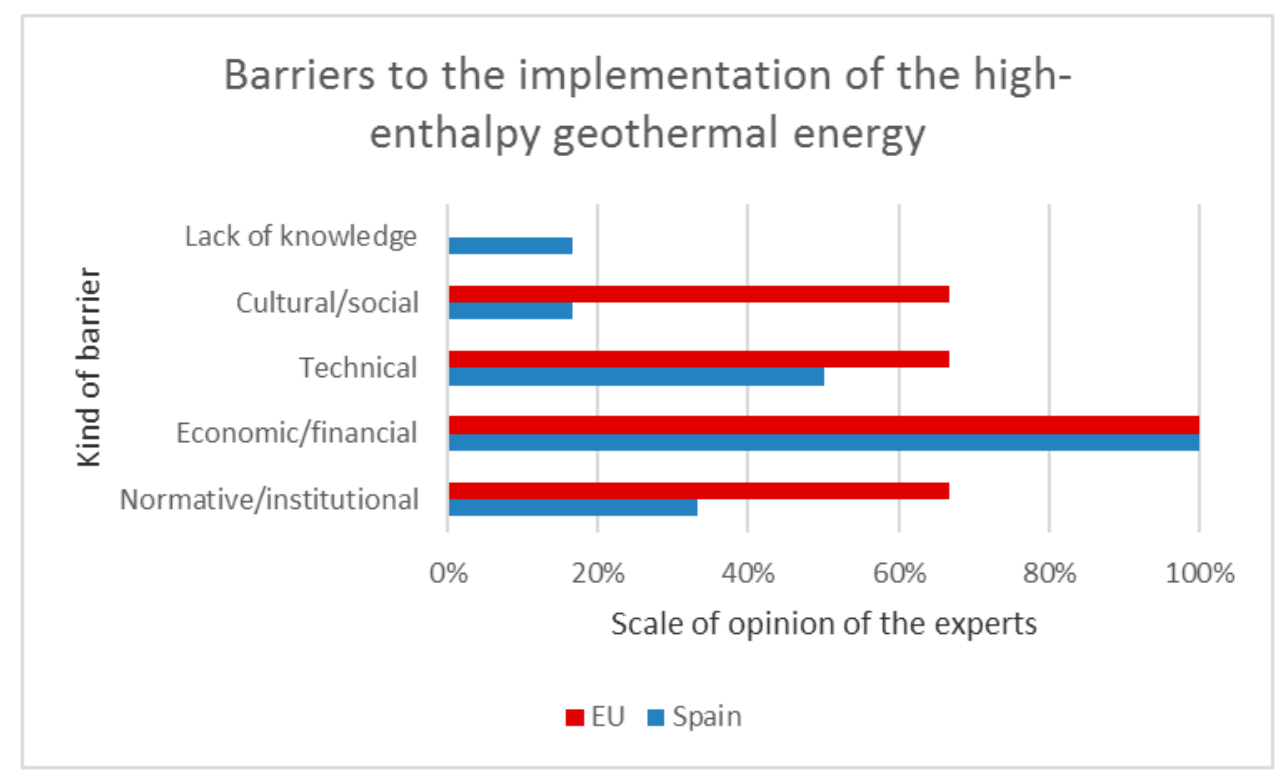

Figure 9. Barriers to the implementation of the high-enthalpy geothermal energy (comparative between Spain and the EU). Source: Own elaboration. 


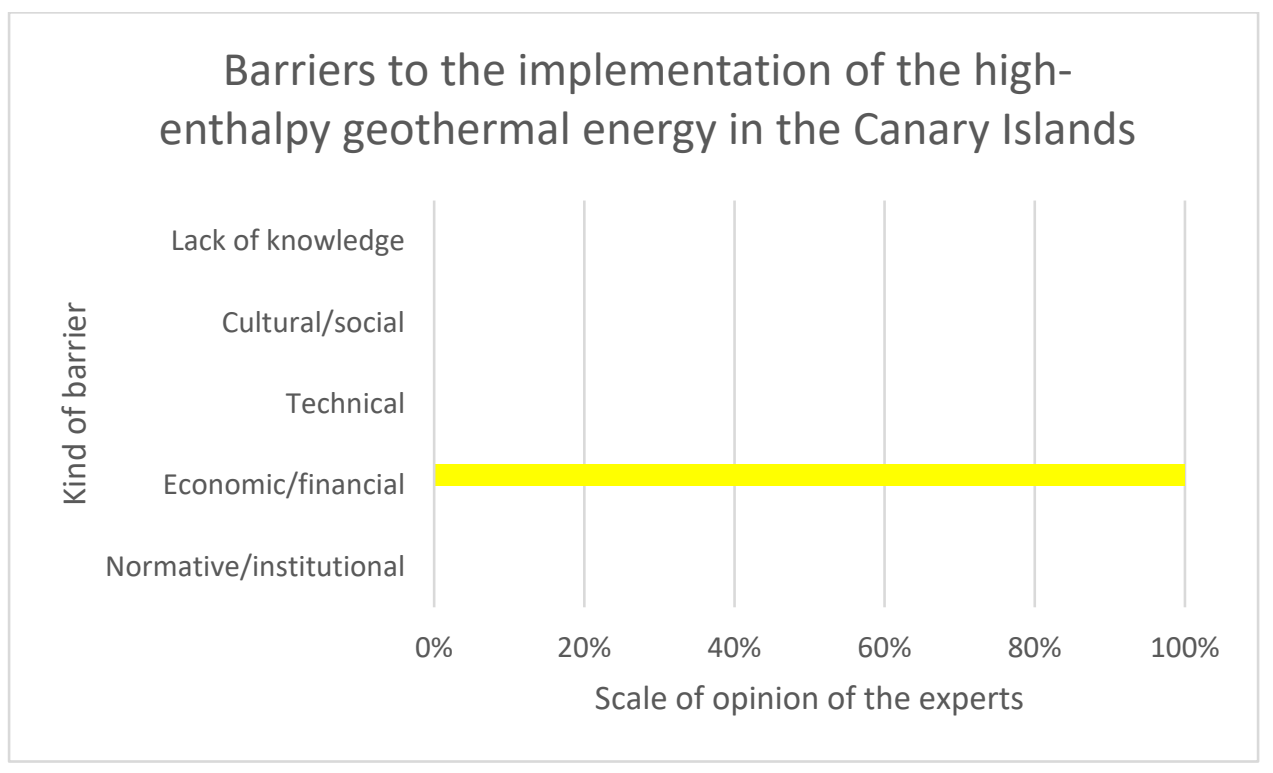

Figure 10. Barriers to the implementation of the high-enthalpy geothermal energy in the Canary Islands. Source: Own elaboration.

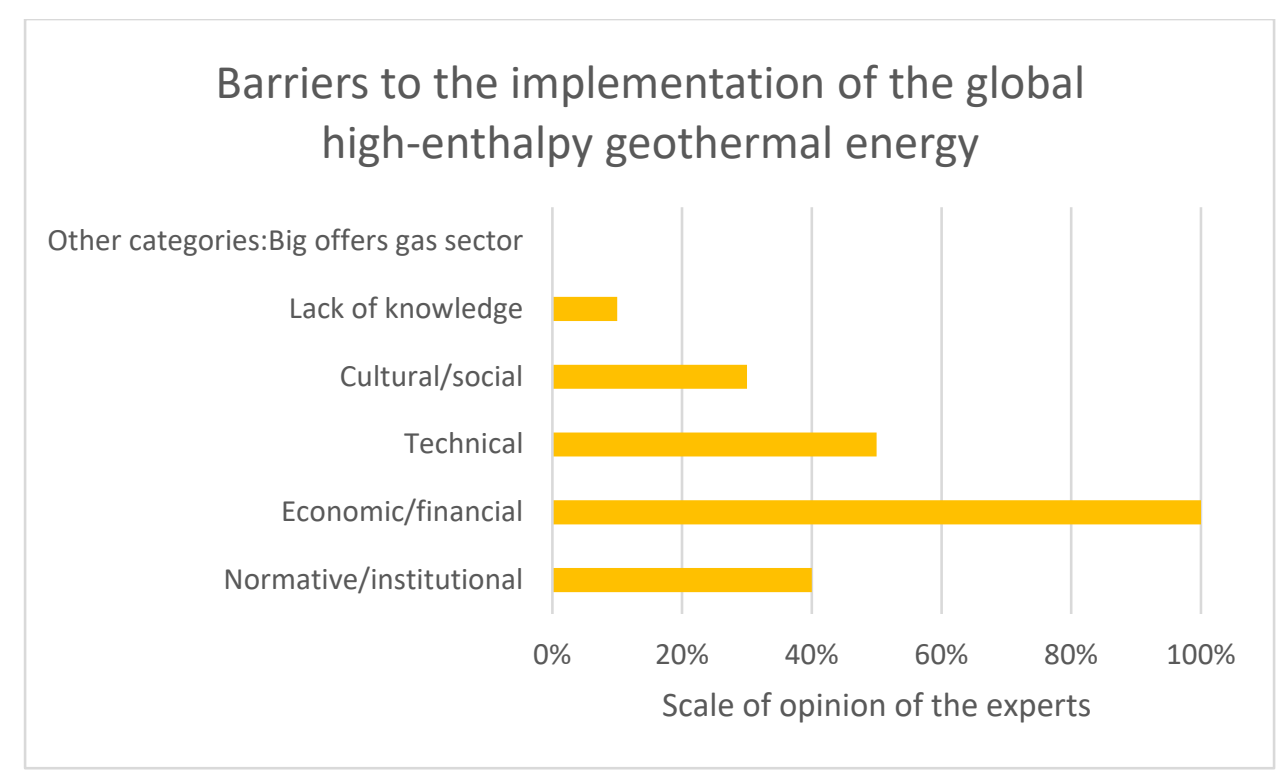

Figure 11. Barriers to the implementation of the global high-enthalpy geothermal energy. Source: Own elaboration.

\subsection{Block 3: Measures}

\subsubsection{Low-Enthalpy Geothermal Energy}

Next, in BLOCK 3, measures to eradicate barriers to low and high-enthalpy geothermal energy and energy mix are examined. Figure 12 compares values in Spain and the EU in the field of low-enthalpy, which are coincident with the fact that the main action to be taken both in Spain and the EU would be promotion. In the case of the EU, public investment is also valued as a key action to take. In the case of the agricultural sector (Figure 13), it would be training and promotion, and for the specific case of the Canary Islands (Figure 14), it would encompass three aspects: training, promotion, and public investment. 


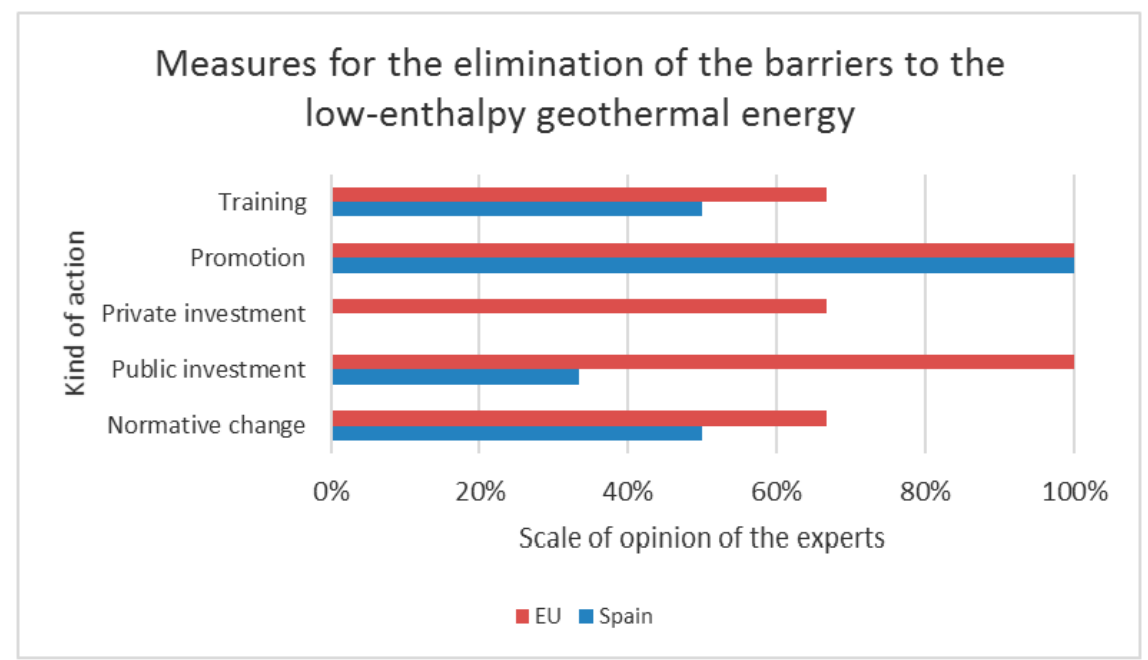

Figure 12. Measures for the elimination of the barriers to the low-enthalpy geothermal energy (comparative between Spain and the EU). Source: Own elaboration.

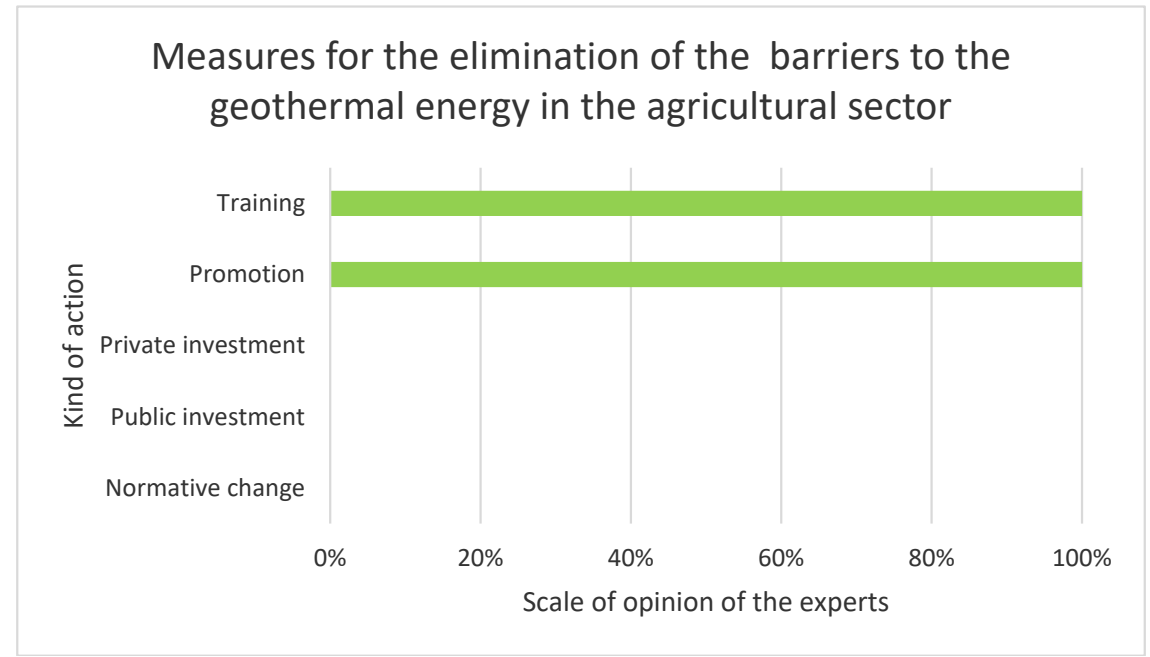

Figure 13. Measures for the elimination of the barriers to the geothermal energy in the agricultural sector. Source: Own elaboration.

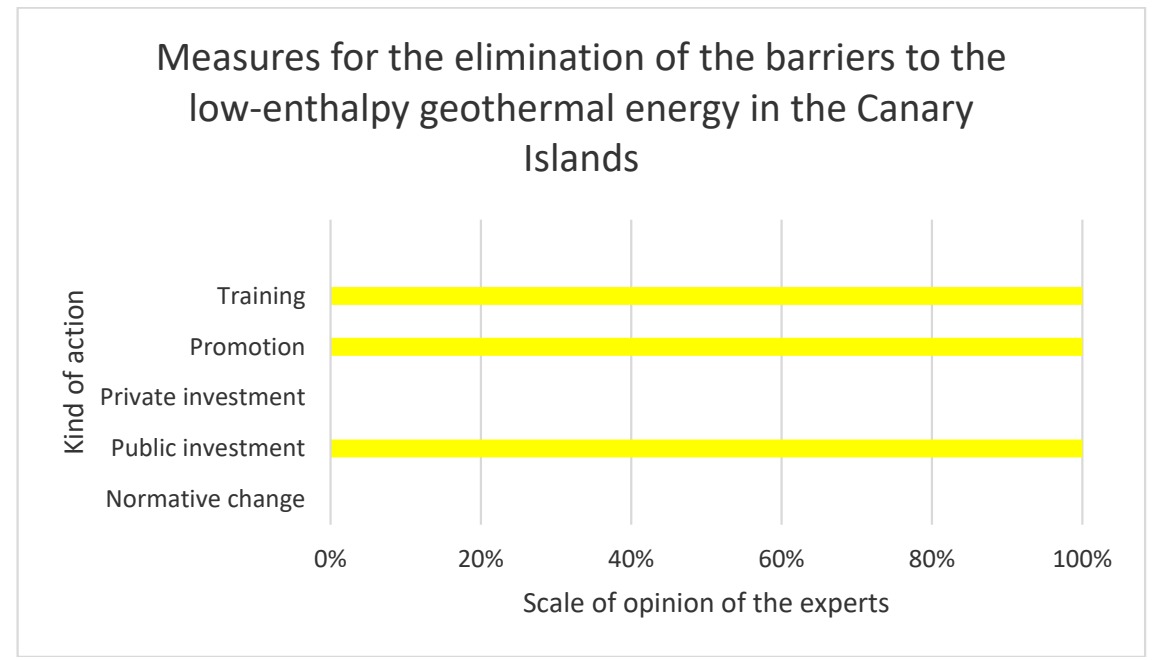

Figure 14. Measures for the elimination of the barriers to the low-enthalpy geothermal energy in the Canary Islands. Source: Own elaboration. 
Figure 15 shows a graph reflecting the opinion of all the experts regarding measures to take to eliminate barriers to low-enthalpy geothermal energy in Spain, the EU, the agricultural sector, and the Canary Islands. It shows how promotion would be the most important action to take, followed by training and public investment.

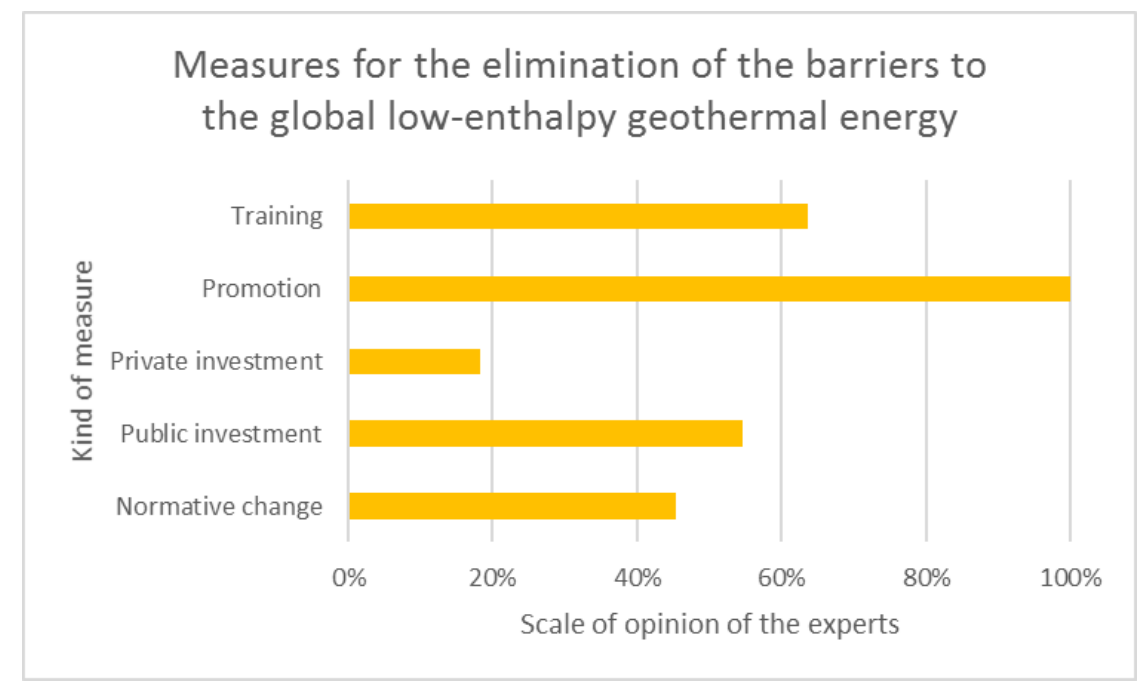

Figure 15. Measures for the elimination of the barriers to the global low-enthalpy geothermal energy. Source: Own elaboration.

\subsubsection{High-Enthalpy Geothermal Energy}

Regarding the steps to take to eradicate barriers to high-enthalpy geothermal energy, we again assess the situation in Spain compared to the EU and the Canary Islands. In this case, the agricultural sector has not been specifically considered regarding high-enthalpy. Figure 16 shows there is no unanimity of judgement of European and Spanish experts since, for the former, the main actions to take would be private investment and promotion, whilst for the latter it would be public investment. In the case of the Canary Islands (Figure 17), it would be public investment and promotion. Examining the situation as a whole for all experts and locations (Figure 18), it would be public investment followed by promotion and private investment. As far as low-enthalpy is concerned, only promotion would be on top.

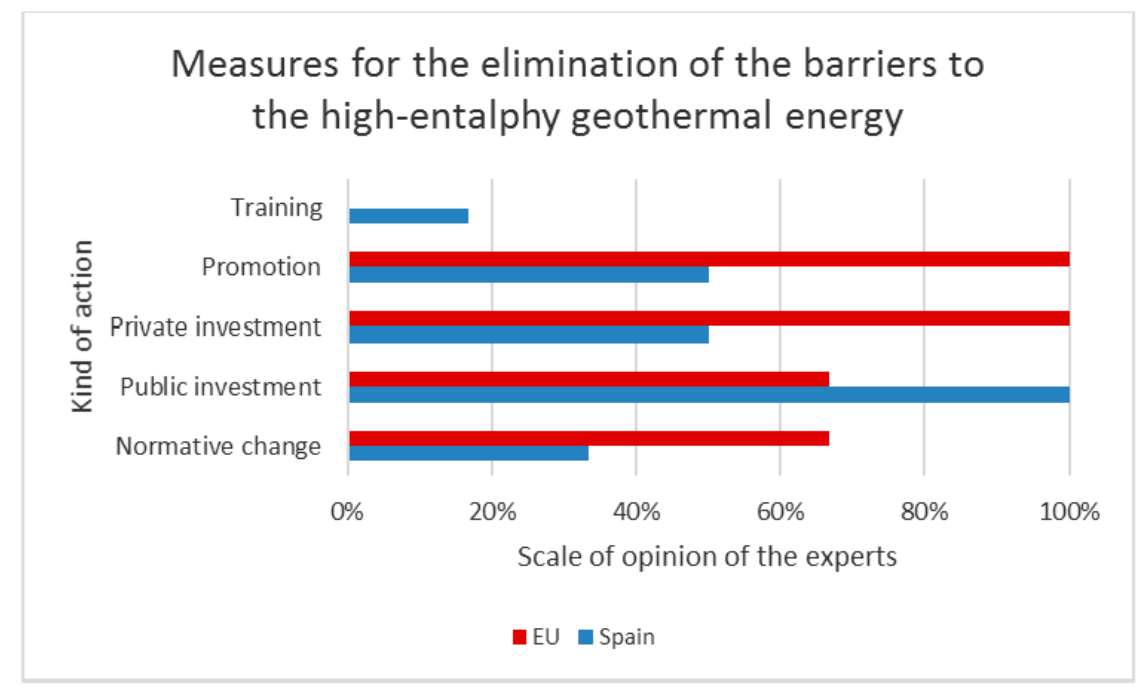

Figure 16. Measures for the elimination of the barriers to the high-enthalpy geothermal energy (comparative between Spain and the EU). Source: Own elaboration. 


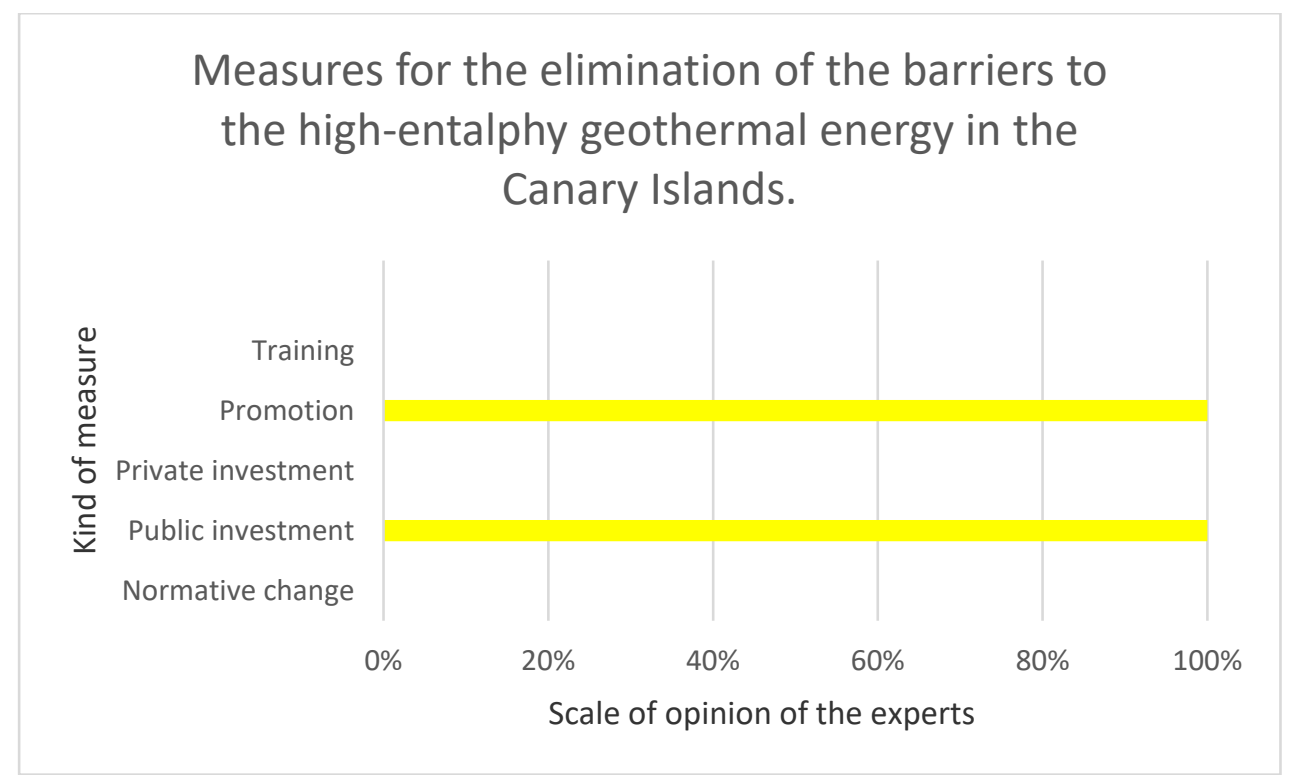

Figure 17. Measures for the elimination of the barriers to the high-enthalpy geothermal energy in the Canary Islands. Source: Own elaboration.

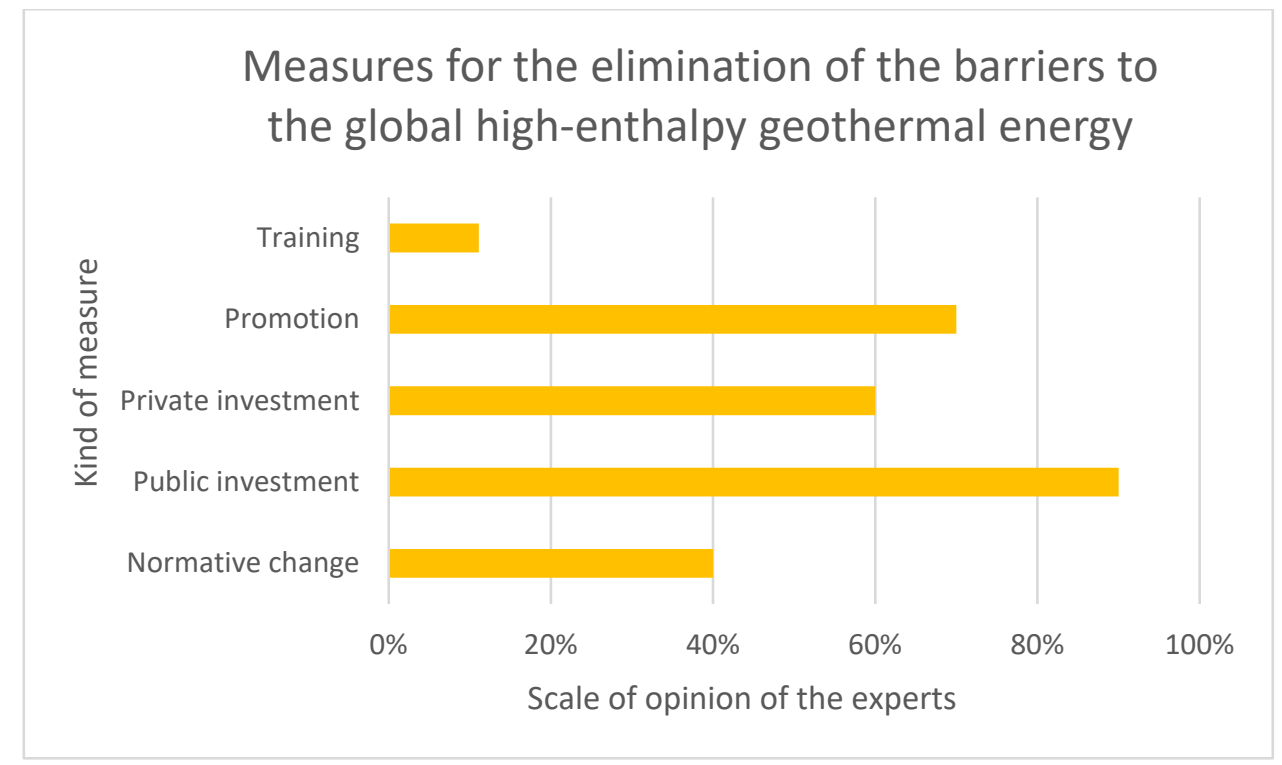

Figure 18. Measures for the elimination of the barriers to the global high-enthalpy geothermal energy. Source: Own elaboration.

\subsubsection{Energy Mix}

The last measures to be assessed are those related to energy mix. Both in the EU and Spain (Figure 19), regulatory change is seen as the most significant step to take and public investment, private investment and promotion follow. In the case of the Canary Islands (Figure 20), the measures are regulatory change and public investment. From a global assessment (Figure 21), regulatory change remains on top, followed closely by investment. 


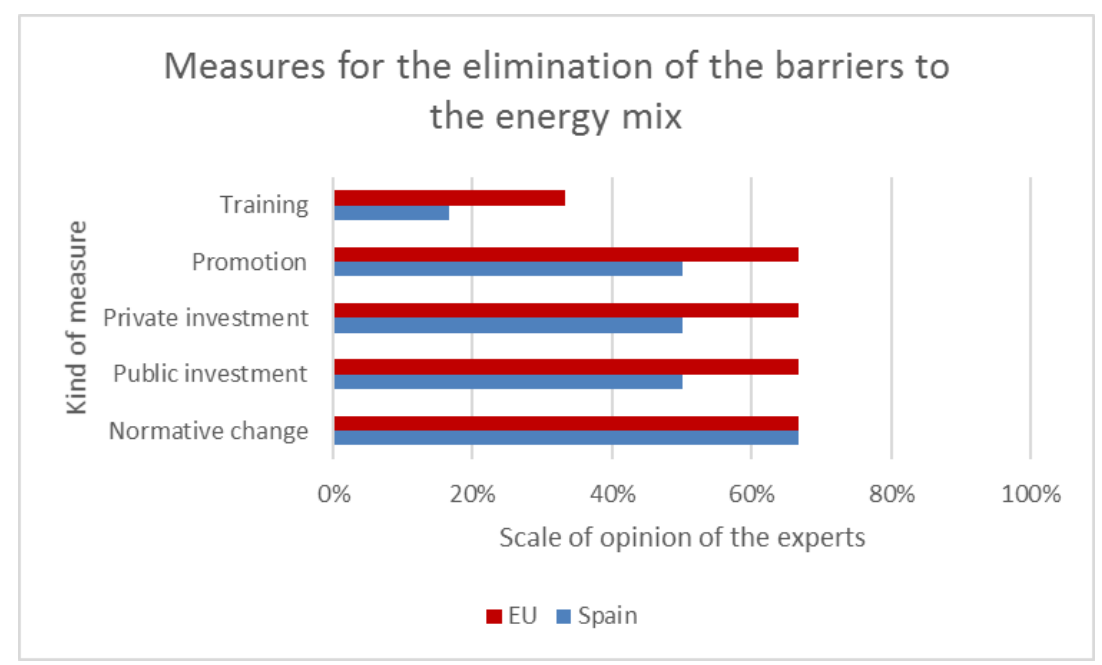

Figure 19. Measures for the elimination of the barriers to the energy mix (comparative between Spain and the EU). Source: Own elaboration.

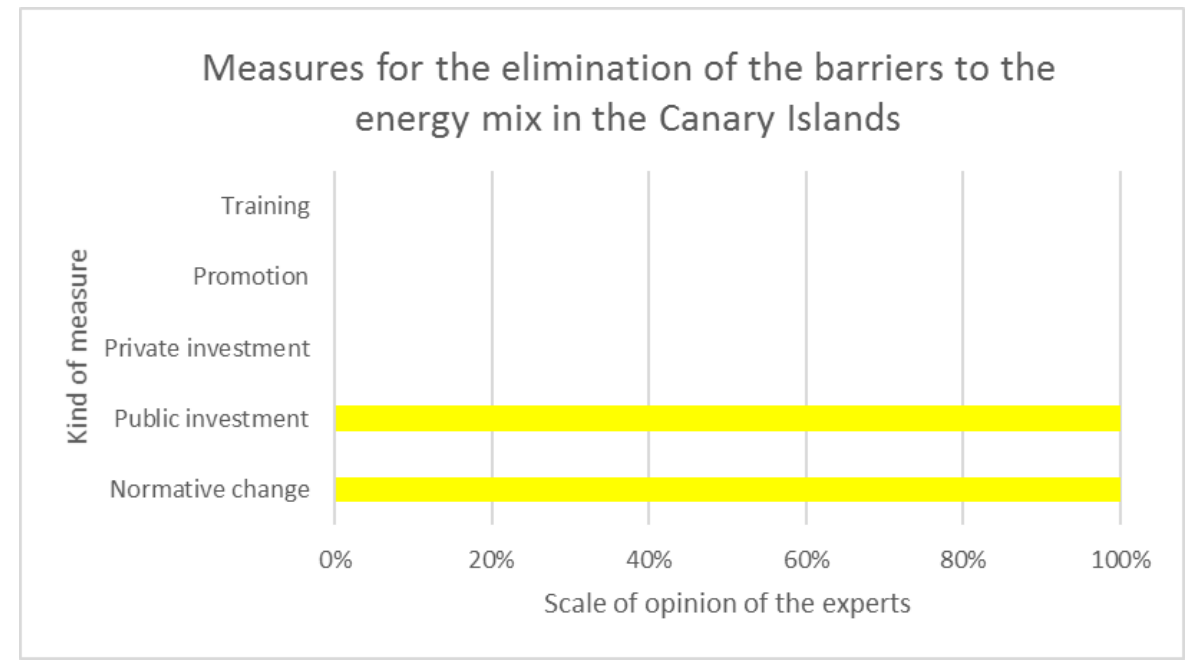

Figure 20. Measures for the elimination of the barriers to the energy mix in the Canary Islands. Source: Own elaboration.

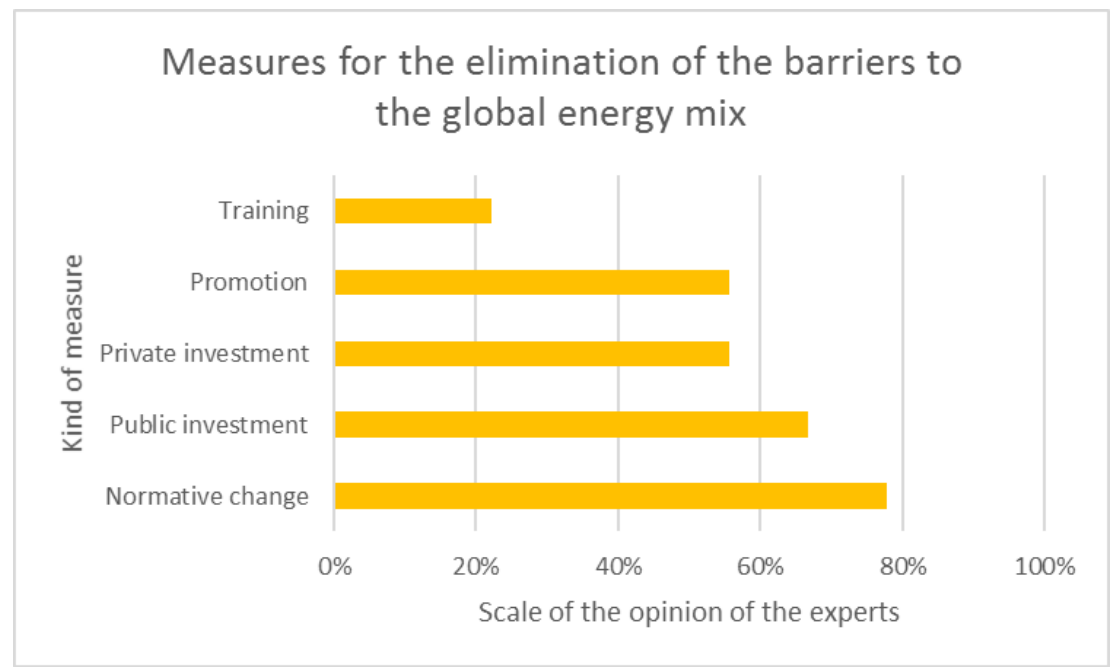

Figure 21. Measures for the elimination of the barriers to the global energy mix. Source: Own elaboration. 


\subsection{Block 4: Advantages}

\subsubsection{Low-Enthalpy Geothermal Energy}

Once barriers and actions to take are addressed, there is a need to know what the real advantages to the introduction of each technology are: these are low-enthalpy, high-enthalpy geothermal and mix, in each one of the scenarios described above. The results are presented on Figures A9-A11 (Appendix C). On Figure A9, the advantage which scores higher in all examined scenarios, Spain, the EU, the agricultural sector, and the Canary Islands is reduction of external energy dependence. Lowest on the list is energy security.

The greatest number of advantages to the implementation of this technology is given by the EU and Canary Islands experts.

\subsubsection{High-Enthalpy Geothermal Energy}

As far as the advantages to the introduction of high-enthalpy geothermal energy are concerned (Figure A10), once again the EU and the Canary Islands would benefit the most. Top of the list for value is $\mathrm{CO}_{2}$ emissions reduction and energy independence. Low on the list are opening to new markets stability of the electrical grid and energy costs reduction.

\subsubsection{Energy Mix}

Regarding energy mix (Figure A11), the greatest advantages would be for Spain and the EU. In this instance, external energy independence followed by energy costs reduction are on top of the list, while on the bottom are opening new markets and local development.

\subsection{Closed Questions Questionnaire}

To obtain a more detailed assessment from the experts, a further questionnaire with 8 closed questions is presented (Appendix D, Table A5) and Figures A12-A19 are also shown on the aforementioned Appendix.

The most promising results on whether further development of geothermal technology would reduce its cost are for the EU, the Canary Islands, and the agricultural sector (Figure A12), and it is in some way consistent with one of the main advantages shown in Figure A9, which is energy cost reduction.

Once again, the most encouraging scenarios are for the EU, the Canary Islands, and the agricultural sector regarding final consumer concerns about the origin of the energy consumed (Figure A13). We must bear in mind that European experts believe that the demands of the citizens from the $\mathrm{N}$ of Europe are greater than those of the $\mathrm{S}$ of Europe.

Also, as previously mentioned, the Michalena and Hills study [13] shows differences between the $\mathrm{N}$ and $\mathrm{S}$ countries of Europe. For example, training and monitoring are more important for $\mathrm{S}$ countries than for $\mathrm{N}$ countries where established local social networks already exist. On the other hand, within the European 2020 strategy [30], differences between N and S are not considered, although they obviously exist. Similarly, subsidiary requirements should be tailored at a regional level [13].

Regarding whether the final consumer is aware of environmental, social, and economic advantages related to the implementation of this technology (Figure A14), there is no unanimity of criteria. The most favorable judgement is for the agricultural sector and for the EU. This question and its answers are consistent with one of the main actions needed to eradicate barriers for this technology: promotion.

In some articles, a parallel is drawn between citizens' income and environmental protection [32]. Also, the higher the level of development of a country, the more the investment in renewable energy [33]. 
Regarding whether the initial investment needs to be larger due to the innovative nature of this technology (Figure A15), the scenarios with the highest score are those of the Canary Islands and the agricultural sector. These answers are consistent with actions needed to eradicate barriers to geothermal energy since investment appeared as one of the main actions to take. Initial investment, together with oil prices, appear to be key financial barriers on previous geothermal studies that consider the agricultural and the livestock sectors. An energy performance contract (EPC) could be the solution to resolve geothermal energy financial barriers. There are examples of energy performance contract in buildings but not in the agricultural or livestock sectors. Primary productive sectors such as agriculture and livestock would benefit from this cost-effective solution using a low-enthalpy geothermal heat pump [24].

In the section of theoretical framework, a study on solar hybridization located in Turkey was cited which, despite the initial investment being larger than that of conventional energies, proved that with sufficient wind load, this combination is preferable to conventional energies [25].

Regarding the question of whether geothermal energy is at a disadvantage due to its costs against other renewable sources (Figure A16), a high percentage of respondents are very clear on the matter and categorical in their judgement for the EU, the Canary Islands, and the agricultural sector.

To the question of whether the government policies can be an obstacle to the introduction of this technology, there is disparity of criteria which ranges from those who, as in the case of the agricultural sector, do not answer to those who agree completely as in the case of the Canary Islands, or half of the respondents in the case of Spain, who believe this to be a hindrance (Figure A17).

Regarding the environmental awareness of companies, there are also some differences of judgement according to the context. It is clear that this is not so in the case of the Canary Islands (Figure A18).

The greatest degree of agreement in this batch of eight questions is reached on question number eight, which refers to whether institutions continue to support fossil fuels and cross-border energy grids to the detriment of renewable energies as a consequence of lobbying. The more a country depends on fossil fuels, the less renewable development it has [32].

Figures A12-A19 reflect the judgement of experts for all possible scenarios and shows score levels. The answer with the highest score is supported from institutions to fossil fuels and cross-border grids. With the lowest score is the question: is the final consumer aware of the environmental, social, and economic advantages and is the current political situation and government policies an obstacle? The first issue could be resolved by regulatory change affecting high-enthalpy geothermal energy rather than low-enthalpy, which seems to keep on progressing in the market. The moratorium on renewable energies should be lifted along with a reform in the electricity sector. Institutions at the national and European level need a strong commitment to implement this kind of technology. Some institutions and individual companies indeed support its development, but there is still a long way to go to achieve large-scale progress [34].

On the matter of the question with the lowest score-Is the consumer aware of environmental, social and economic advantages? - training and promotion are needed.

As stated in the section on the theoretical framework, there are numerous applications for geothermal energy, and many cases have already been studied, although many of them are still in the pilot phase [34]. It seems necessary to develop all these projects to move on from the pilot stage and enter the market. This will only come to fruition with due training and promotion.

\section{Conclusions}

The fact of being able to discriminate in this study according to the different uses of geothermal energy (thermal or electrical or mix) depending on the region examined (island, country, or continent) or even including a specific activity sector, in this case agricultural, though it could be any other, allows us to focus attention where it is really needed and to identify the actions more fit for each case. 
This work contemplates four big blocks, namely the degree of implementation, barriers, measures and advantages for the three technologies and the four scenarios mentioned in it, thus moving from a global approach to a more specific one and analyzing its results.

The main conclusions of this study are as follows. First, regarding level of implementation of this energy, a lower degree in Spain than in the EU has been identified for all the examined scenarios except for low-enthalpy geothermal energy. It is even lower in the Canary Islands than in the main land in all scenarios except for the geothermal energy mix. On a general level, the degree of development turned out to be two for underdevelopment on a 1 to 5 scale (from lowest to highest), the situation being poorer as far as high-enthalpy geothermal energy is concerned as well as geothermal energy on the agricultural sector.

Second, regarding barriers, when discriminating renewable energies by type and thus separating geothermal from the rest and even its thermal or electrical end uses as in the research that concerns us, we find that economic barriers to low-enthalpy geothermal energy in Spain are not as significant as might be expected and that, in fact, this score is lower than its European counterparts. On the other hand, in the case of high-enthalpy geothermal energy production, economic barriers are high both in Spain and in the rest of Europe. On a global scale, the study concludes that the main barriers to the introduction of electrical uses for geothermal energy are economic/financial, while for thermal uses, they are cultural or social. At a regional level, in the EU economic/financial barriers are still the most important, both for low and high-enthalpy geothermal. This is also true in Spain, although in the latter case to a lesser extent. In the case of the Canary Islands, the main barriers are cultural/social along with regulatory/institutional for low-enthalpy geothermal energy and economic/financial for high-enthalpy geothermal energy.

As stated previously, one of the most commonly cited topics in a variety of articles $[35,36]$ is the importance of implementation of renewable energies at a local level, although European policies (and not only in Europe) give minimal support to this issue.

According to the findings of the research carried out here, the institutional or regulatory barriers rank third on the general scale for both high and low enthalpy, being more important in the EU than in Spain especially for electrical uses. As indicated above, the importance of the Canary Islands is also worth mentioning in this case.

In the third place, the measures to be taken, this study concludes that at the regional level, the EU considers that the actions to be taken are private investment in the case of high-enthalpy geothermal energy and promotion for low-enthalpy geothermal energy. In the case of Spain, for the high-enthalpy geothermal energy, it would be public investment and, again, promotion for thermal uses. In the case of the Canary Islands, public investment for low and high-enthalpy, training, and promotion for low-enthalpy. In the agricultural sector, training and promotion would be the most significant measures both for renewable energy in general as well as for geothermal energy in particular. Regarding global actions, depending on whether it is low-enthalpy geothermal, high-enthalpy geothermal or energy mix, public investment, promotion, and regulatory change in this order.

The figures show that when examining barriers to the introduction of renewable energies by focusing on geothermal energy in particular and its energy mix, it is not only promotion and regulatory that change rank on the first positions but also private and public investment, being of more or less importance depending on the region case study and the type of geothermal technology.

Lastly, as far as advantages are concerned, energy security does not seem to be the main concern of experts since this is covered by other sources of energy in the short term (renewable and non-renewable). This is more relevant in the Canary Islands due to its isolated and insular nature. Nonetheless, our study does share with others the crucial importance of energy independence from external sources [37]. The case of the Canary Islands is not different from the rest of the insular areas in Europe and worldwide, where distributed generation and micro-grids become a fundamental issue. For all three technologies that have been studied here-low-enthalpy, high-enthalpy, and energy mix - the EU scenario is the most positive. This circumstance is repeated in all questionnaires. 
A study with more subject matter experts in the field would be desirable in the future when this technology will be well known, to evaluate its differences to the current one. In the same way, it is expected that future research in the line proposed here include new technologies such as dry hot rock, stimulated geothermal systems, or supercritical deposits.

Author Contributions: E.P.-T. and E.R.-A. designed and performed the experimental and theoretical basis of the research. E.P.-T. implemented the methodology and calculations and analyzed the results. E.R.-A. provided technical and theoretical support. E.P.-T. wrote the manuscript and all authors read and approved the final version.

Funding: This research received no external funding.

Acknowledgments: This article would have not been possible without the help of the following entities, organizations and companies that we would like to thank for their participation in the surveys: Almunia Solar, APPA: Association of renewable energy companies, CIEMAT: Center for energy, environmental and technological research, COSVIG: Consorzio per lo Sviluppo delle Aree Geotermiche, EGEC: European Geothermal Congress, FENERCOM: Energy Foundation of the Community of Madrid, IGME: Geological and Miner Institute of Spain, LIAG-HANNOVER: Leibniz institute for Applied Geophysics, UB: University of Barcelona, ULL: University of La Laguna.

Conflicts of Interest: The authors declare no conflict of interest.

\section{Abbreviations}

$\begin{array}{ll}\text { DK/DA } & \text { Doesn't know/doesn't answer } \\ \text { N/S } & \text { North/South } \\ \text { y/n } & \text { yes/no } \\ \text { European Union } & \text { EU }\end{array}$

\section{Appendix A}

Four questionnaire models were elaborated with Google Docs and experts considered most suitable for each region pertinent to the study were invited to reply via e-mail.

Below is a summary of the links and forms that were sent to experts.

Form 1: European Union

https://docs.google.com/forms/d/1qSAmdOFryKOqJ78Wi5BRftkLtXH3dYCrfJ4mGhVdKN4/edit.

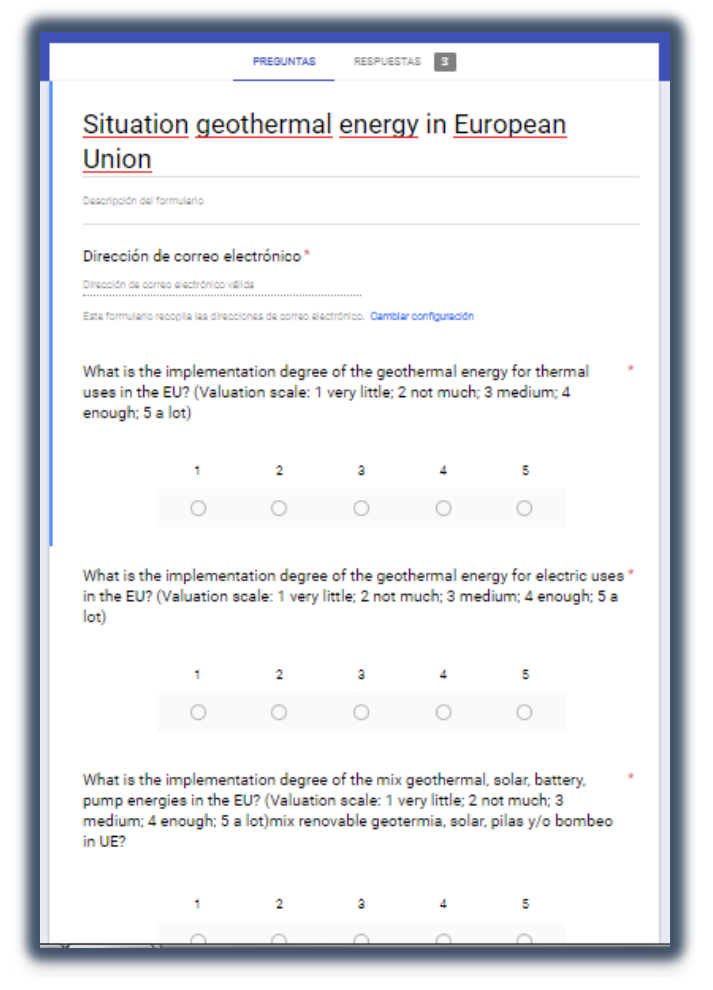

Figure A1. Form model EU. Source: Own elaboration. 
Form 2: Spain

https://docs.google.com/forms/d/1jEkObggXyDD_8pdcfKkulz3vnxaWtfsl21QyhXUbKlE/edit.

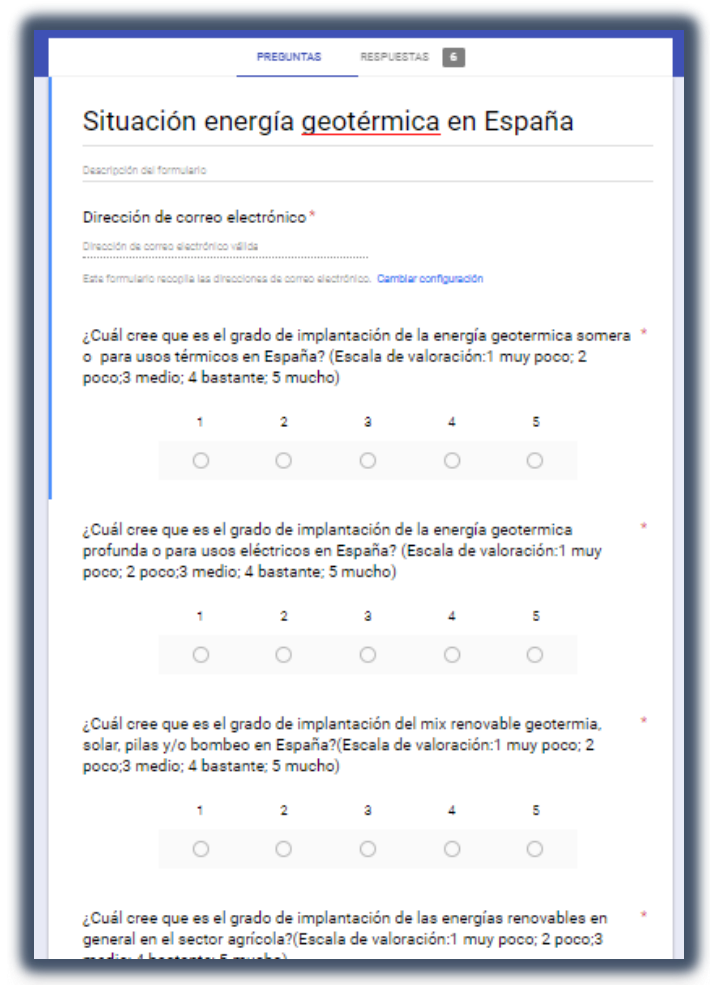

Figure A2. Form model Spain. Source: Own elaboration.

Form 3: Canary Islands https:/ / docs.google.com/forms/d/1H0sIcClMp1Mk7J9Xt8Z-36BZkJBSvb8c2qok6leIS28/edit.

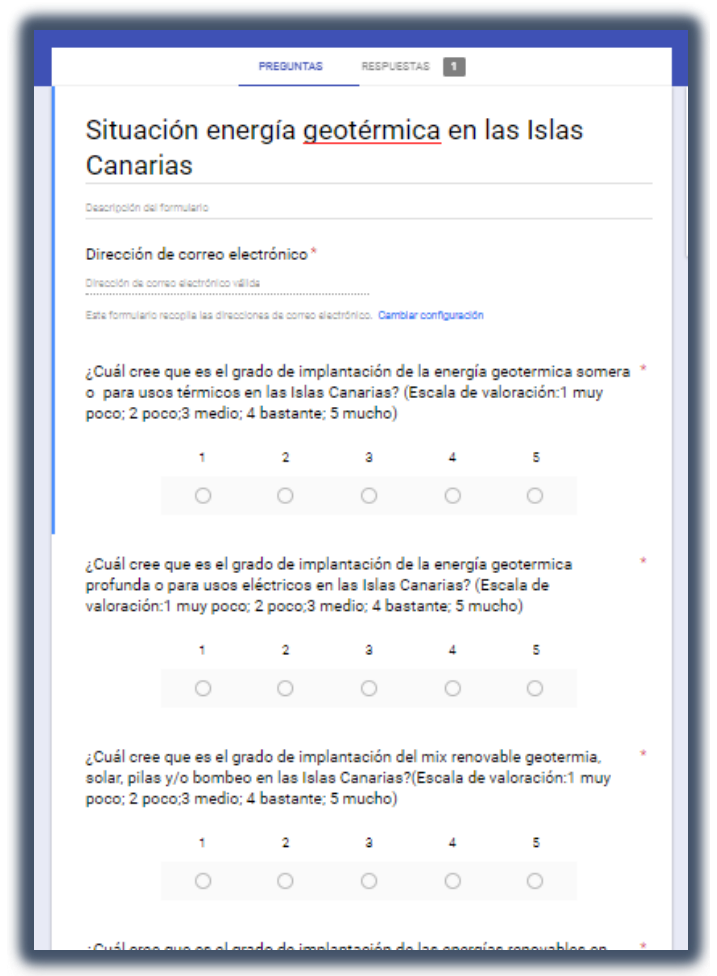

Figure A3. Form model Canary Islands. Source: Own elaboration. 
Form 4: Agricultural sector

https://docs.google.com/forms/d/12jxJ_Ek35RCKlWfzcZo53y_XCln5hOvJNkpnz1DvIDg/edit.

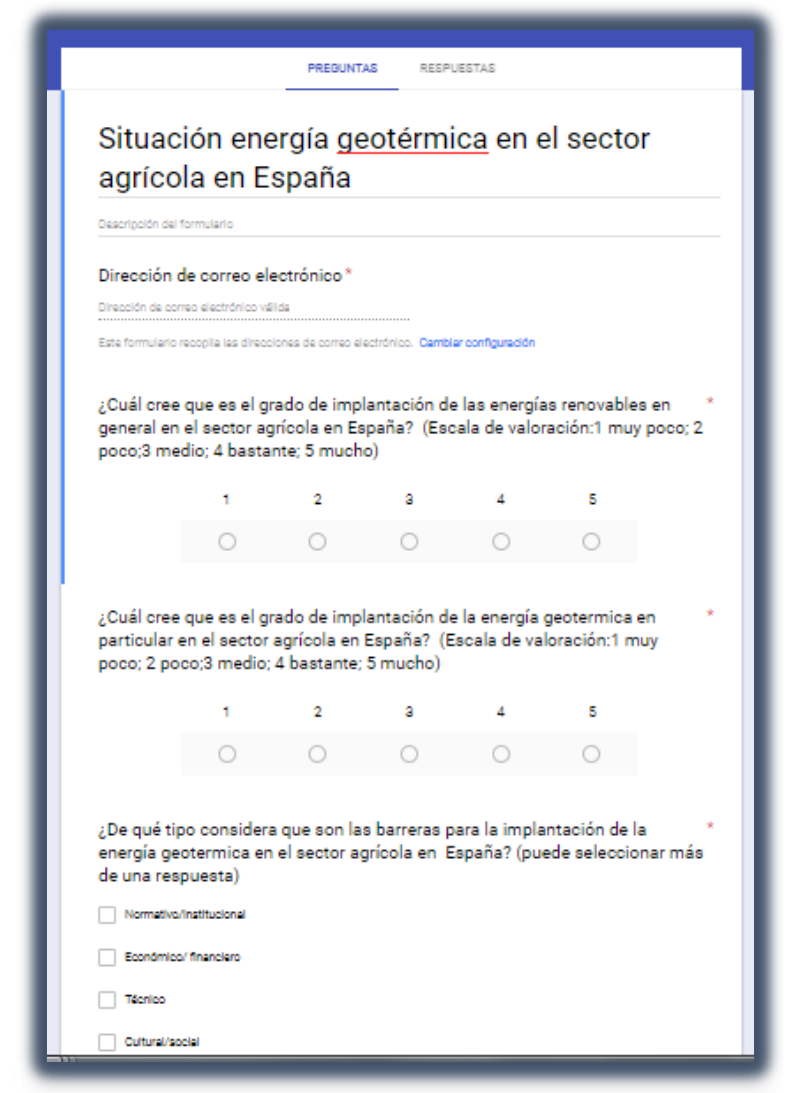

Figure A4. Form model agricultural sector. Source. Own elaboration.

\section{Appendix B}

Block 1: Level of implementation

In this first block, the level of implementation of geothermal energy for each of scenario and technologies shown in Figure 1 is examined. We work with a scoring scale of 1: very little to 5: a lot. See Figure A5 and Table A1.
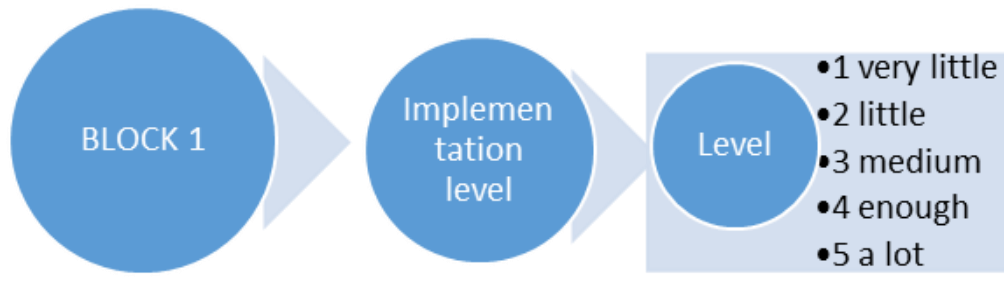

Figure A5. Implementation level for low-enthalpy, high-enthalpy and mix geothermal energy in Spain, EU, Canary Islands, and agricultural sector. Source: Own elaboration. 
Table A1. Questions regarding the implementation level of geothermal energy for each of the four scenarios proposed: Spain, EU, Canary Islands, and agricultural sector. Source: Own elaboration.

\begin{tabular}{|c|c|c|c|c|c|c|}
\hline \multirow[b]{2}{*}{ BLOCK } & \multicolumn{2}{|l|}{ SCENARIO } & \multirow{2}{*}{$\frac{1}{\text { SPAIN }}$} & \multirow{2}{*}{2} & \multirow{2}{*}{$\begin{array}{c}3 \\
\text { CANARY } \\
\text { ISLANDS }\end{array}$} & \multirow{2}{*}{$\begin{array}{c}4 \\
\begin{array}{c}\text { AGRICULTURAL } \\
\text { SECTOR }\end{array}\end{array}$} \\
\hline & QUESTIONS & $\begin{array}{l}\text { SCORING } \\
\text { SCALE }\end{array}$ & & & & \\
\hline \multirow{24}{*}{1} & & 1: very little & & & \multirow{24}{*}{ Figures $2-4$} & \\
\hline & What do you think is the & 2: little & & & & \\
\hline & implementation level for the & 3: medium & & & & \\
\hline & low-enthalpy geothermal energy? & 4: enough & & & & \\
\hline & & 5: a lot & & & & \\
\hline & & 1: very little & & & & \\
\hline & What do you think is the & 2: little & & & & \\
\hline & implementation level for the & 3: medium & & & & \\
\hline & high-enthalpy geothermal energy? & 4: enough & & & & \\
\hline & & 5: a lot & & & & \\
\hline & & 1: very little & & & & \\
\hline & implementation level for the mix & 2: little & & & & \\
\hline & renewable: geothermal, solar, battery & 3: medium & & & & \\
\hline & and/or pumping? & $\begin{array}{l}\text { 4: enough } \\
5: \text { a lot }\end{array}$ & & & & \\
\hline & & 1: very little & & & & \\
\hline & What do you think is the & 2: little & & & & \\
\hline & implementation level for the renewable & 3: medium & & & & \\
\hline & energy in the agricultural sector? & 4: enough & & & & \\
\hline & \multirow{6}{*}{$\begin{array}{l}\text { And the geothermal energy in } \\
\text { particular in the agricultural sector? }\end{array}$} & 5: a lot & & & & \\
\hline & & 1: very little & & & & \\
\hline & & 2: little & & & & \\
\hline & & 3: medium & & & & \\
\hline & & 4: enough & & & & \\
\hline & & 5: a lot & & & & \\
\hline
\end{tabular}

Block 2: Barriers

In this second block, barriers to the introduction of all types of geothermal energy and in the 4 scenarios-Spain, the EU, the Canary Islands, and the agricultural sector-are studied, for which a series of multi-answers are established (Figure A6 and Table A2).
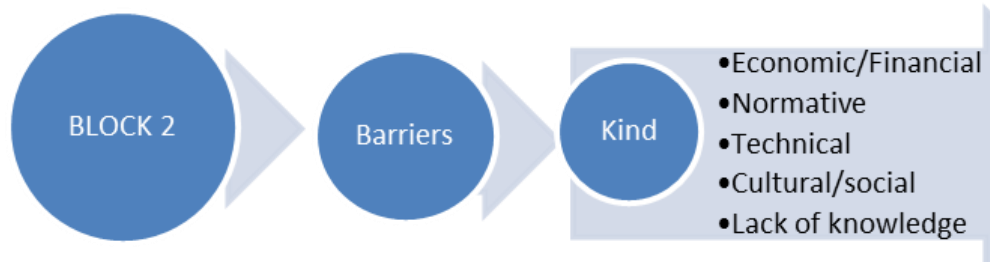

Figure A6. Barriers to the implementation of the low- and high-enthalpy geothermal energy and mix energy in Spain, EU, Canary Islands, and agricultural sector. Source: Own elaboration.

Table A2. Questions regarding the barriers to the implementation of geothermal energy for each of the four scenarios proposed: Spain, EU, Canary Islands, and agricultural sector. Source: Own elaboration.

\begin{tabular}{|c|c|c|c|c|c|c|}
\hline \multirow[b]{2}{*}{ BLOCK } & \multicolumn{2}{|c|}{ SCENARIO } & \multirow{2}{*}{$\begin{array}{c}1 \\
\text { SPAIN }\end{array}$} & \multirow{2}{*}{$\begin{array}{c}2 \\
\mathrm{EU}\end{array}$} & \multirow{2}{*}{$\begin{array}{c}3 \\
\text { CANARY } \\
\text { ISLANDS }\end{array}$} & \multirow{2}{*}{$\begin{array}{c}4 \\
\text { AGRICULTURAL } \\
\text { SECTOR }\end{array}$} \\
\hline & QUESTIONS & MULTI ANSWERS & & & & \\
\hline 2 & $\begin{array}{l}\text { Which among these do you think } \\
\text { are the barriers to the } \\
\text { implementation of low-enthalpy } \\
\text { geothermal energy? } \\
\text { Which among these do you think } \\
\text { are the barriers to the } \\
\text { implementation of high-enthalpy } \\
\text { geothermal energy? }\end{array}$ & $\begin{array}{l}\text { Economic/Financial } \\
\text { Normative } \\
\text { Technical } \\
\text { Cultural/social } \\
\text { Lack of knowledge } \\
\text { Others; Big offers gas sector } \\
\text { Economic/Financial } \\
\text { Normative } \\
\text { Technical } \\
\text { Cultural/social } \\
\text { Lack of knowledge } \\
\text { Others; Big offers gas sector }\end{array}$ & & & Figures $5-11$ & \\
\hline
\end{tabular}


Block 3: Measures

In this third block, the most appropriate actions to take toward the eradication of barriers to the introduction of all types of geothermal energy are studied: thermal, electrical and mix uses for the four proposed scenarios. Also, the methodology in this case consists of a series of multi-answers.
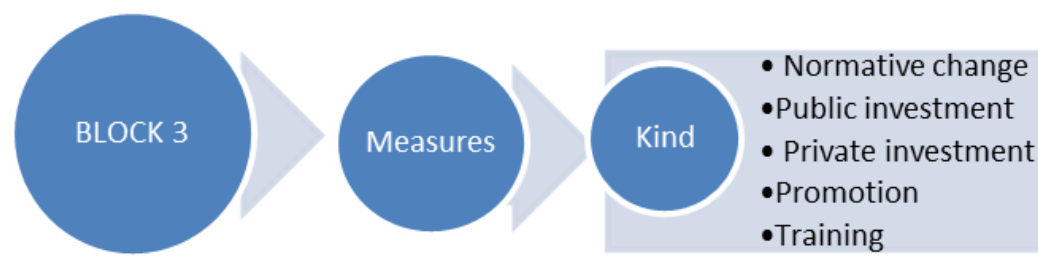

Figure A7. Measures to eliminate barriers to the implementation of low- and high-enthalpy geothermal energy, and mix energy in Spain, EU, Canary Islands, and the agricultural sector. Source: Own elaboration.

Table A3. Questions related to the measures that eliminate barriers to the implementation of geothermal energy for each of the four proposed scenarios. Source: Own elaboration.

\begin{tabular}{|c|c|c|c|c|c|c|}
\hline \multirow[b]{2}{*}{ BLOCK } & \multicolumn{2}{|c|}{ SCENARIO } & \multirow{2}{*}{$\begin{array}{c}1 \\
\text { SPAIN }\end{array}$} & \multirow{2}{*}{$\begin{array}{c}2 \\
\mathrm{EU}\end{array}$} & \multirow{2}{*}{$\begin{array}{c}3 \\
\text { CANARY } \\
\text { ISLANDS }\end{array}$} & \multirow{2}{*}{$\begin{array}{c}4 \\
\begin{array}{c}\text { AGRICULTURAL } \\
\text { SECTOR }\end{array}\end{array}$} \\
\hline & QUESTIONS & MULTI ANSWERS & & & & \\
\hline \multirow{14}{*}{3} & & Normative change & & & \multirow{14}{*}{ Figures 12-21 } & \\
\hline & What would be the most & Public investment & & & & \\
\hline & appropriate measures for the & Private investment & & & & \\
\hline & geothermal energy barriers? & Promotion & & & & \\
\hline & & Training & & & & \\
\hline & What would be the most & $\begin{array}{l}\text { Normative change } \\
\text { Public investment }\end{array}$ & & & & \\
\hline & appropriate measures for the & $\begin{array}{l}\text { Public investment } \\
\text { Private investment }\end{array}$ & & & & \\
\hline & elimination of high-enthalpy & Promotion & & & & \\
\hline & geothermal energy barriers? & Training & & & & \\
\hline & What would be the most & Normative change & & & & \\
\hline & What would be the most & Public investment & & & & \\
\hline & appropriate measures for the & Private investment & & & & \\
\hline & $\begin{array}{l}\text { elimination of renewable } \\
\text { energy mix barriers? }\end{array}$ & Promotion & & & & \\
\hline & & Training & & & & \\
\hline
\end{tabular}

Block 4: Advantages

In this last block, a series of advantages are laid out to see the most appropriate based on the criteria from the experts for each of the scenarios and proposed technologies.

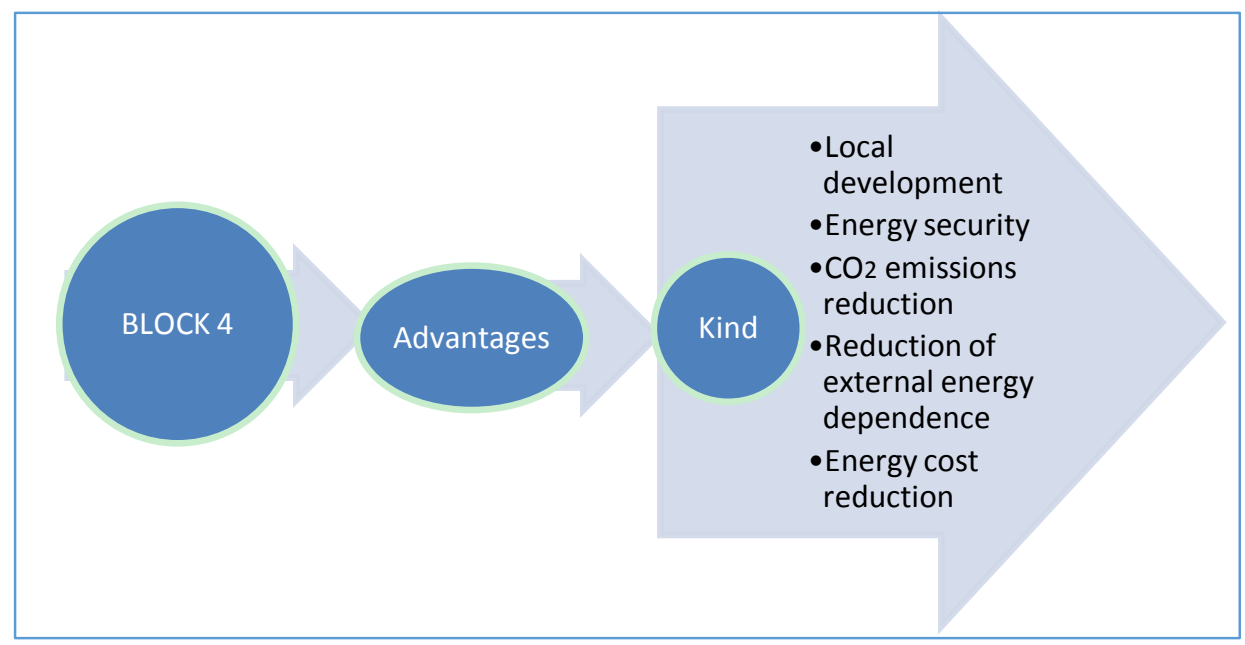

Figure A8. Advantages of the implementation of low, high enthalpy geothermal energy and mix renewable energy in Spain, EU, Canary Islands, and agricultural sector. Source: Own elaboration. 
Table A4. Questions related to the advantages of the implementation of geothermal energy for each of the four proposed scenarios: Spain, EU, Canary Islands, and the agricultural sector. Source: Own elaboration.

\begin{tabular}{|c|c|c|c|c|c|c|}
\hline \multirow[b]{2}{*}{ BLOCK } & \multicolumn{2}{|r|}{ SCENARIOS } & \multirow{2}{*}{$\begin{array}{c}1 \\
\text { SPAIN }\end{array}$} & \multirow{2}{*}{$\begin{array}{c}2 \\
\mathrm{EU}\end{array}$} & \multirow{2}{*}{$\begin{array}{c}3 \\
\text { CANARY } \\
\text { ISLANDS }\end{array}$} & \multirow{2}{*}{$\begin{array}{c}4 \\
\begin{array}{c}\text { AGRICULTURAL } \\
\text { SECTOR }\end{array}\end{array}$} \\
\hline & QUESTIONS & MULTI ANSWERS & & & & \\
\hline 4 & $\begin{array}{l}\text { What advantages would } \\
\text { a greater development of } \\
\text { low-enthalpy geothermal } \\
\text { energy have? } \\
\text { What advantages would } \\
\text { a greater development of } \\
\text { high-enthalpy geothermal } \\
\text { energy have? } \\
\text { What advantages would } \\
\text { a greater development of } \\
\text { renewable mix } \\
\text { energy have? }\end{array}$ & $\begin{array}{l}\text { Local development } \\
\text { Energy security } \\
\mathrm{CO}_{2} \text { emissions reduction } \\
\text { Reduction of external energy dependence } \\
\text { Energy cost reduction } \\
\text { Local development. } \\
\text { Energy security } \\
\mathrm{CO}_{2} \text { emissions reduction } \\
\text { Reduction of external energy dependence } \\
\text { Energy cost reduction } \\
\text { Local development } \\
\text { Energy security } \\
\mathrm{CO}_{2} \text { emissions reduction } \\
\text { Reduction of external energy dependence } \\
\text { Energy cost reduction }\end{array}$ & & & Figures A9- & \\
\hline
\end{tabular}

\section{Appendix C}

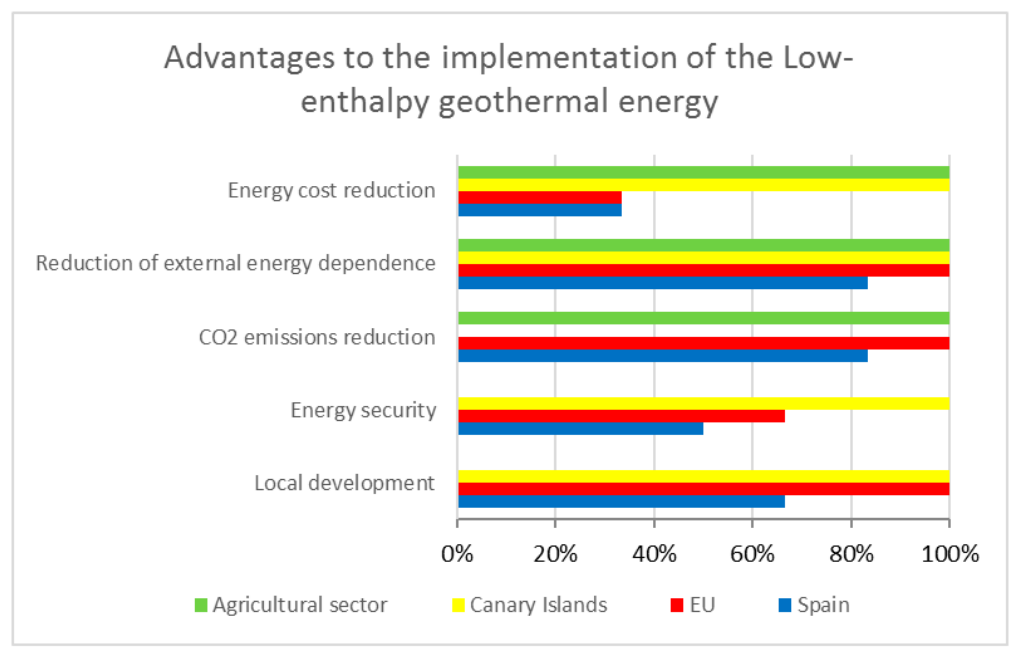

Figure A9. Advantages to the implementation of the low-enthalpy geothermal energy. Source: Own elaboration.

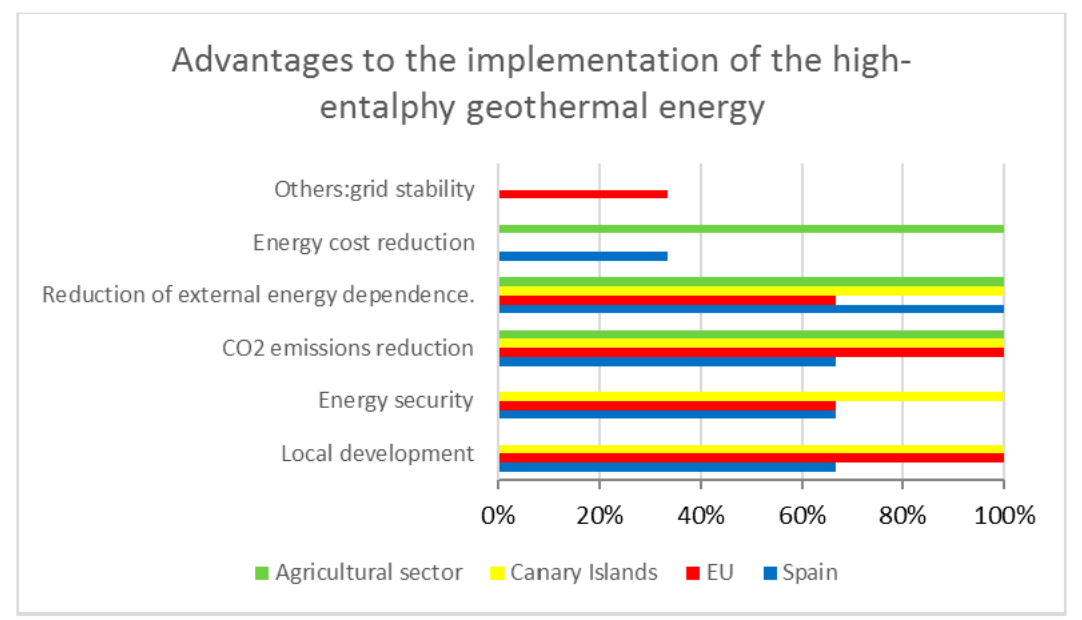

Figure A10. Advantages to the implementation of the high-enthalpy geothermal energy. Source: Own elaboration. 


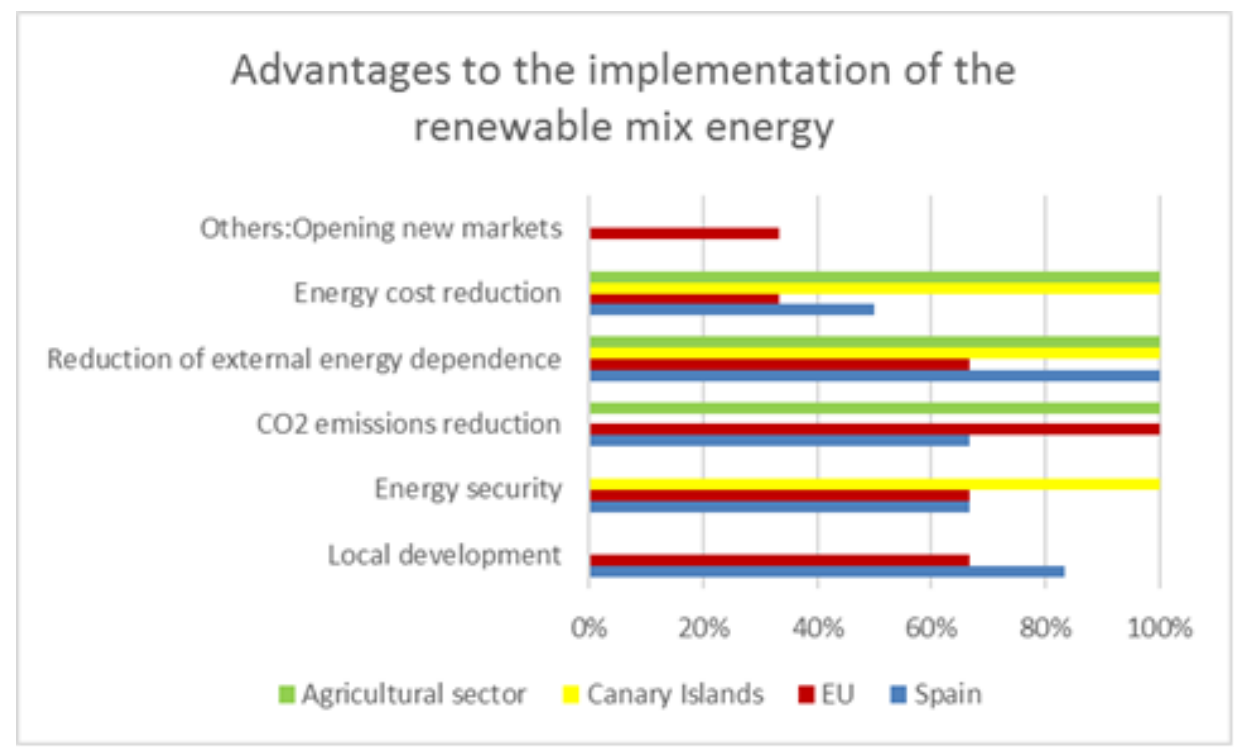

Figure A11. Advantages to the implementation of the mix renewable energy. Source: Own elaboration.

\section{Appendix D}

Table A5. Closed questions related to the situation of geothermal energy and other renewable energies in the context and proposed scenarios. Source: Own elaboration.

\begin{tabular}{|c|c|c|c|c|c|}
\hline SCENARIOS & & 1 & 2 & 3 & 4 \\
\hline QUESTIONS & ANSWERS & SPAIN & EU & $\begin{array}{l}\text { CANARY } \\
\text { ISLANDS }\end{array}$ & $\begin{array}{l}\text { AGRICULTURAL } \\
\text { SECTOR }\end{array}$ \\
\hline & & & & \multirow{24}{*}{ Figures A12- } & \\
\hline $\begin{array}{l}\text { this technology (low- and/or } \\
\text { high-enthalpy geothermal energy and/or }\end{array}$ & $\begin{array}{l}\text { Yes } \\
\text { No }\end{array}$ & & & & \\
\hline energy mix with other sources of energy) & $\mathrm{DK} / \mathrm{DA}$ & & & & \\
\hline Do you think that the final consumer is & Yes & & & & \\
\hline becoming more demanding with the & No & & & & \\
\hline origin of the energy he (she) consumes? & $\mathrm{DK} / \mathrm{DA}$ & & & & \\
\hline Do you believe that the final consumer is & Yes & & & & \\
\hline aware of the environmental, social and & No & & & & \\
\hline $\begin{array}{l}\text { economic benefits of clean } \\
\text { energy consumption? }\end{array}$ & $\mathrm{DK} / \mathrm{DA}$ & & & & \\
\hline Do you think that the initial investment & Yes & & & & \\
\hline is greater due to the use of a & No & & & & \\
\hline new technology? & DK/DA & & & & \\
\hline Do you think that geothermal energy is at & Yes & & & & \\
\hline a cost disadvantage with other renewable & No & & & & \\
\hline energies of greater implantation? & $\mathrm{DK} / \mathrm{DA}$ & & & & \\
\hline Do you think that the current government & Yes & & & & \\
\hline situation is an obstacle on the & No & & & & \\
\hline implementation of this technology? & $\mathrm{DK} / \mathrm{DA}$ & & & & \\
\hline Do you think that companies are & Yes & & & & \\
\hline increasingly aware of environmental & No & & & & \\
\hline issues beyond purely economic ones? & $\mathrm{DK} / \mathrm{DA}$ & & & & \\
\hline \multirow{3}{*}{$\begin{array}{l}\text { Do you think that the institutions continue } \\
\text { to support fossil fuels and the creation of } \\
\text { cross-border energy networks to the } \\
\text { detriment of local renewable energies? }\end{array}$} & Yes & & & & \\
\hline & No & & & & \\
\hline & $\mathrm{DK} / \mathrm{DA}$ & & & & \\
\hline
\end{tabular}




\section{Do you think that further development of this} technology would reduce its cost?

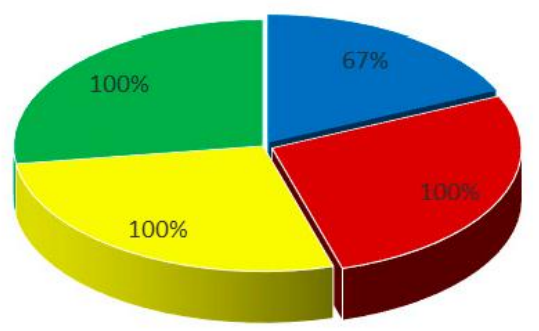

Dpain - EU = Canarylslands - Agricultural sector

Figure A12. Comparative between development of the technology and cost reduce in the proposed scenarios Percentages in the graph showed for Yes. Source: Own elaboration.

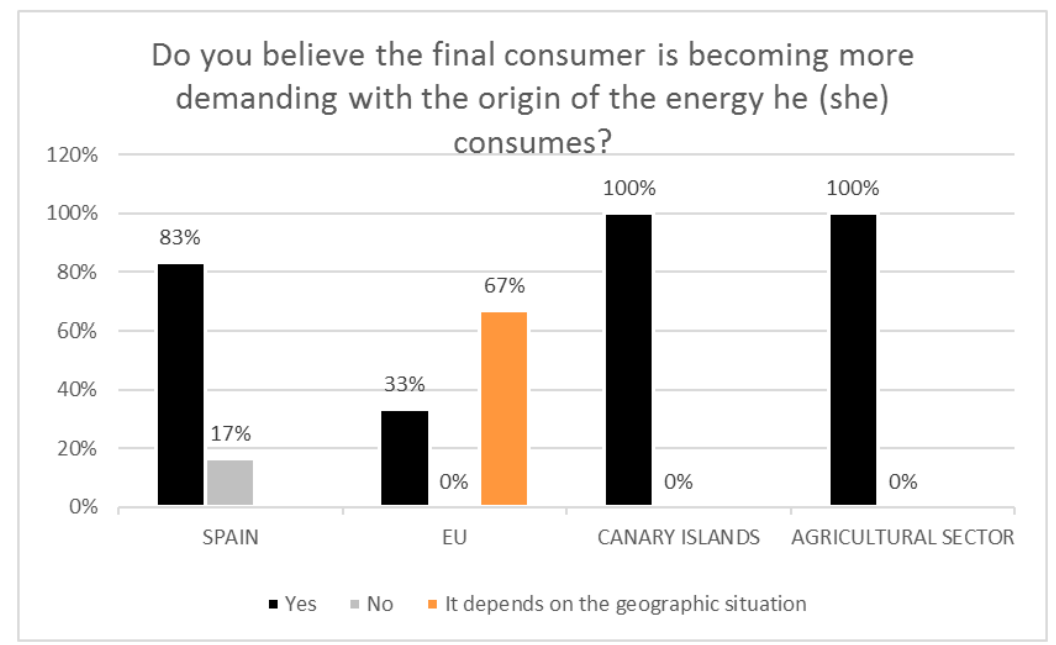

Figure A13. Comparative between demanding of the final consumer and the origin of the energy he (she) consumes in the four proposed scenarios: Spain, EU, Canary Islands, and agricultural sector. Source: Own elaboration.

Do you believe that the final consumer is aware of the environmental, social and economic benefits of clean energy consumption?

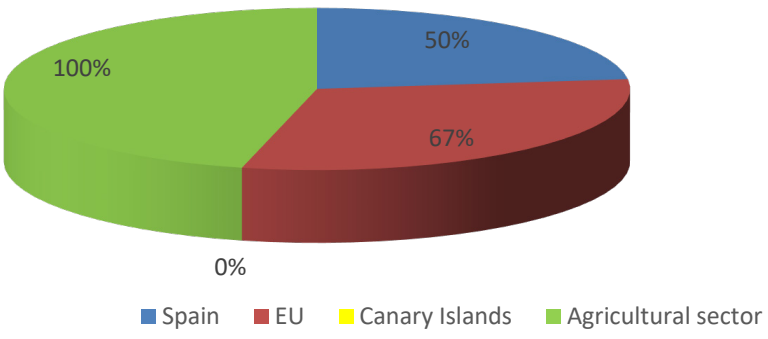

Figure A14. Comparison between the final consumer awareness and the advantages of clean energy consumption in the four proposed scenarios: Spain, EU, Canary Islands, and the agricultural sector. Percentages in the graph showed for Yes. Source: Own elaboration. 


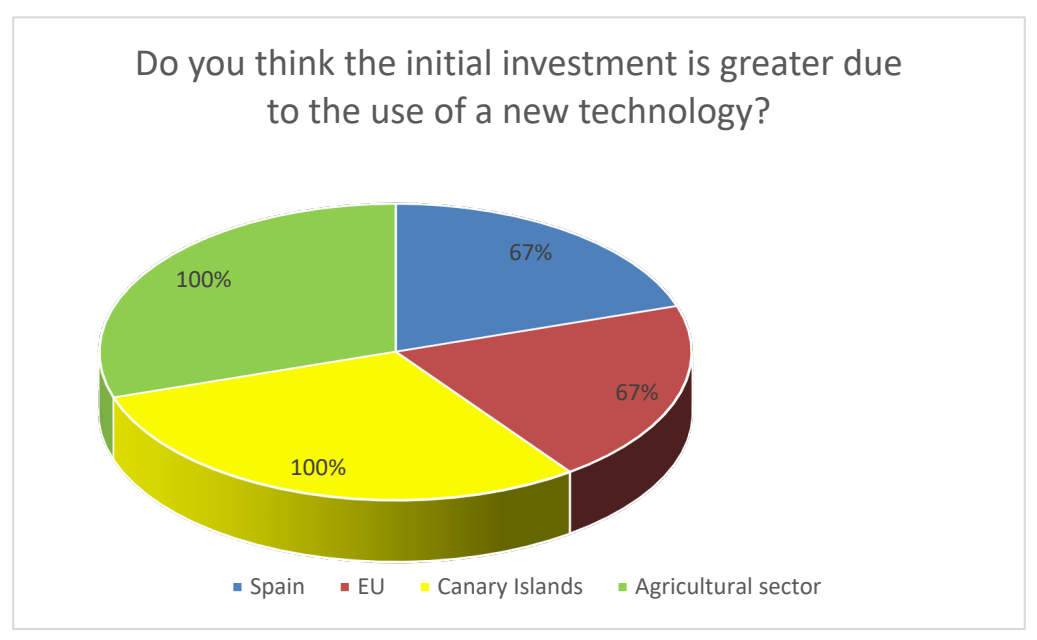

Figure A15. Comparison between initial investment and the use of a new technology in the four scenarios proposed: Spain, EU, Canary Islands, and the agricultural sector. Percentages in the graph showed for Yes. Source: Own elaboration.

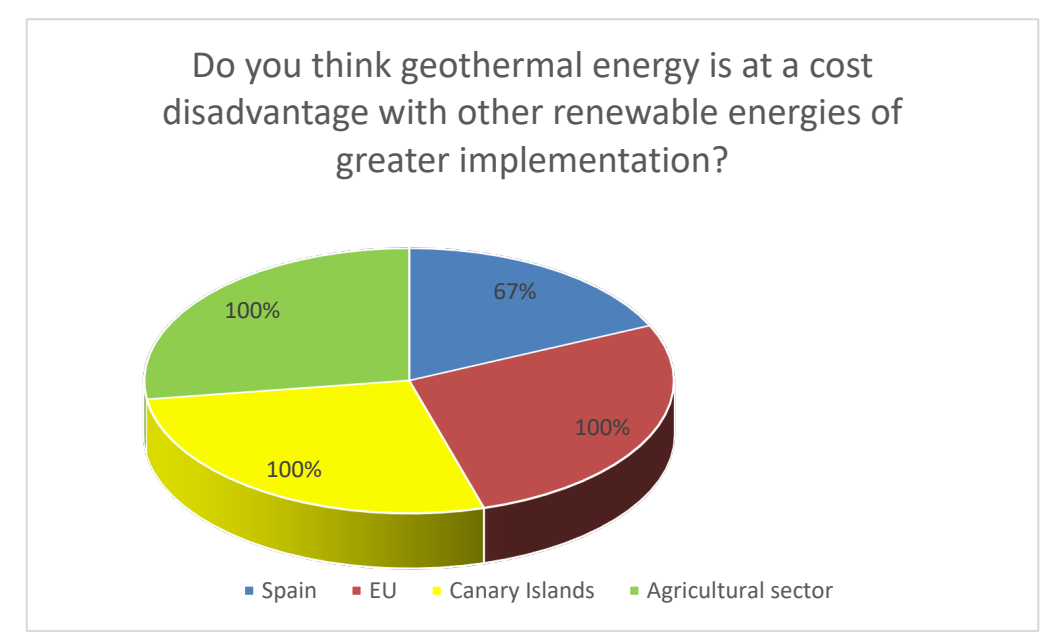

Figure A16. Comparison between disadvantage in cost of the geothermal energy and other renewables energies in the four proposed scenarios: Spain, EU, Canary Islands, and the agricultural sector. Percentages in the graph showed for Yes. Source: Own elaboration.

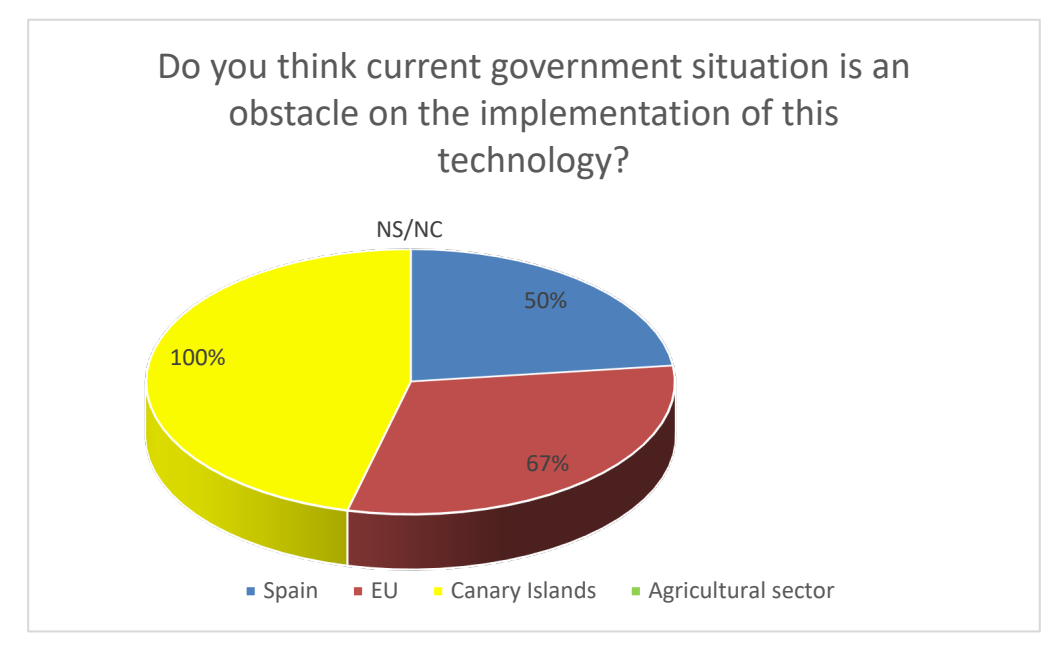

Figure A17. Comparison between current government situation and the impediment to the implementation of the geothermal energy in the four scenarios proposed: Spain, EU, Canary Islands, and the agricultural sector Percentages in the graph showed for Yes. Source: Own elaboration. 


\section{Do you think companies are increasingly aware of environmental issues beyond purely economic ones?}

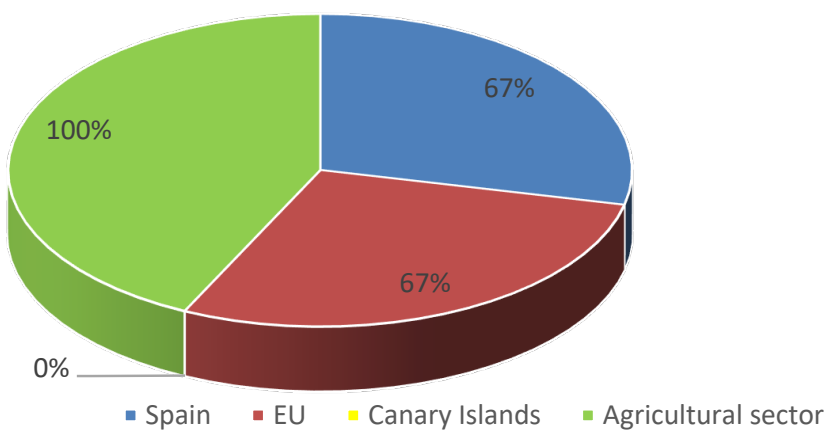

Figure A18. Comparison between awareness of the companies about environmental issues in the four scenarios proposed: Spain, EU, Canary Islands, and the agricultural sector. Percentages in the graph showed for Yes. Source: Own elaboration.

\section{Do you think the institutions continue to support fossil fuels and the creation of cross-border energy networks to the detriment of local renewable energies?}

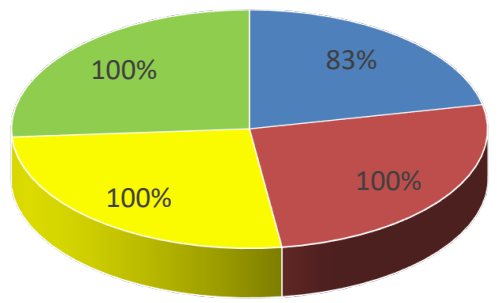

- Spain - EU $=$ Canary Islands $=$ Agricultural sector

Figure A19. Comparison between support for the institutions to the fossil fuels and cross-border energy networks to the detriment of local energies in the four proposed scenarios: Spain, EU, Canary Islands, and the agricultural sector Percentages in the graph showed for Yes. Source: Own elaboration.

\section{References}

1. Lucas, H.; Fifita, S.; Talab, I.; Marschel, C.; Cabeza, L. Critical challenges and capacity building needs for renewable energy deployment in Pacific Small Island Developing States (Pacific SIDS). Renew. Energy 2017, 107, 42-52. [CrossRef]

2. Sanyé-Mengual, E.; Romanos, H.; Molina, C.; Oliver, M.A.; Ruiz, N.; Pérez, M. Environmental and self-sufficiency assessment of the energy metabolism of tourist hubs on Mediterranean Islands: The case of Menorca (Spain). Energy Policy 2014, 65, 377-387. [CrossRef]

3. Declaración de Madrid. Cumbre Para las Interconexiones Energéticas España-Francia-Portugal-Unión Europea; Declaración de Madrid: Madrid, Spain, 2015. 
4. Energías Renovables. Más Interconexiones Sin Más Renovables No Harán Más Competitiva a la Industria Europea. Available online: https:/ / www.energias-renovables.com/panorama/más-interconexiones-sinmas-renovables-no-haran-20150311 (accessed on 31 August 2017).

5. Ramón Ducoy, F.J. Implantación de Energías Renovables En una Planta de Producción de Amoniaco; Universidad de Sevilla: Proyecto fin de carrera, Spain, 2012.

6. Compromiso Empresarial. Geotermia: Energía Desde el Corazón de la Tierra. Available online: http:/ / www. compromisoempresarial.com/rsc/2014/04/geotermia-energia-desde-el-corazon-de-la-tierra (accessed on 31 August 2017).

7. Economou, A. Renewable energy resources and sustainable development in Mykonos (Greece). Renew. Sustain. Energy Rev. 2010, 14, 1496-1501. [CrossRef]

8. Karagiannis, I.C.; Soldatos, P.G. Estimation of critical $\mathrm{CO}_{2}$ values when planning the power source in water desalination: The case of the small Aegean islands. Energy Policy 2010, 38, 3891-3897. [CrossRef]

9. Giatrakos, G.; Tsoutsos, T.D.; Zografakis, N. Sustainable power planning for the island of Crete. Energy Policy 2009, 37, 1222-1238. [CrossRef]

10. Michalena, E.; Hills, J. Renewable energy issues and implementation of European energy policy: The missing generation? Energy Policy 2012, 45, 201-216. [CrossRef]

11. Nguyen, M.V.; Arason, S.; Gissurarson, M.; Pálsson, P.G. Uses of Geothermal Energy in Food and Agriculture: Opportunities for Developed Countries; Food and Agriculture Organization of the United Nations (FAO): Rome, Italy, 2015.

12. Instituto Geológico y Minero (IGME). Casos Prácticos Geotermia. Available online: http:/ / www.igme.es / Geotermia/Ficheros\%20PDF/Contenido.pdf (accessed on 24 April 2017).

13. Sibbitt, B.; McClenahan, D.; Djebbar, R.; Thornton, J.; Wong, B.; Carriere, J. The performance of a high solar fraction seasonal storage district heating system-Five years of operation. Energy Procedia 2012, 30, 856-865. [CrossRef]

14. Comisión Europea. Multiplaying Sustainable Energy Communities-A Blue Print for Actions. Available online: http:/ / ec.europa.eu/energy/intelligent/projects/en/partners/stadtwerke-crailsheimgmbh (accessed on 24 August 2017).

15. Wesselink, M.; Liu, W.; Koornneef, J.; Van den Broek, M. Conceptual market potential framework of high temperature aquifer thermal energy storage a case study in the Netherlands. Energy 2018, 147, 477-489. [CrossRef]

16. Romero-Rubio, C.; de Andrés Díaz, J.R. Sustainable energy communities: A study contrasting Spain and Germany. Energy Policy 2015, 85, 397-409. [CrossRef]

17. Büyüközkan, G.; Güleryüz, S. Evaluation of Renewable Energy Resources in Turkey using an integrated MCDM approach with linguistic interval fuzzy preference Relations. Energy 2017, 123, 149-163. [CrossRef]

18. Boie, I.; Fernandes, C.; Frías, P.; Klobasa, M. Efficient strategies for the integration of renewable energy into future energy infrastructures in Europe-An analysis based on transnational modeling and case studies for nine European regions. Energy Policy 2014, 67, 170-185. [CrossRef]

19. Borge-Diez, D.; Colmenar-Santos, A.; Pérez-Molina, C.; López-Rey, A. Geothermal source heat pumps under energy services companies finance scheme to increase energy efficiency and production in stockbreeding facilities. Energy 2015, 88, 821-836. [CrossRef]

20. Ozgener, O. Use of solar assisted geothermal heat pump and small wind turbine systems for heating agricultural and residential buildings. Energy 2010, 35, 262-268. [CrossRef]

21. Bhattacharya, M.; Churchill, S.A.; Paramati, S.R. The dynamic impact of renewable energy and institutions on economic output and $\mathrm{CO}_{2}$ emissions across regions. Renew. Energy 2017, 111, 157-167. [CrossRef]

22. Dael, M.V.; Lizin, S.; Swinnen, G.; Van Passel, V. Young people's acceptance of bioenergy and the influence of attitude strength on information provision. Renew. Energy 2017, 107, 417-430. [CrossRef]

23. Cagno, E.; Trianni, A.; Worrel, E.; Miggiano, F. Barriers and drivers for energy efficiency: Different perspectives from an exploratory study in the Netherlands. Energy Procedia 2014, 61, 1256-1260. [CrossRef]

24. Lin, B.; Omoju, O.E. Focusing on the right targets. Economic factors driving non-hydro renewable energy transition. Renew. Energy 2017, 113, 52-63. [CrossRef]

25. Martín Romero, C. Metodología de investigación en estudios de usuarios. Revista General de Información y Documentación 2007, 17, 129-149. 
26. Sustersic, V.M.; Babic, M.J.; Gordic, D.S.; Despotovic, M.; Milovanovic, D.M. An overview of the regulatory framework for the geothermal energy in Europe and Serbia. Therm. Sci. 2010, 14, s115-s123. [CrossRef]

27. Comisión Europea. Acción Por el Clima. Paquete de Medidas Sobre Clima y Energía Hasta el 2020. Available online: https:/ / ec.europa.eu/clima/policies/strategies/2020_es (accessed on 15 February 2018).

28. Sardosky, P. Renewable energy consumption and income in emerging economies. Energy Policy 2009, 37, 4021-4028.

29. Marques, A.C.; Fuinhas, J.A.; Manso, J.R.P. Motivations driving renewable energy in European countries: A panel data approach. Energy Policy 2010, 38, 6877-6885. [CrossRef]

30. Asociación de Empresas de Energías Renovables. Estudio del Impacto Macroeconómico de las Energías Renovables en España 2015; Asociación de Productores de Energías Renovables (APPA): Madrid, Spain, 2016.

31. Goosen, M.; Mahmoudi, H.; Ghaffour, N. Water Desalination Using Geothermal Energy. Energies 2010, 3, 1423-1442. [CrossRef]

32. Blázquez, C.S.; Martín, A.F.; Nieto, I.M.; González-Aguilera, D. Economic and Environmental Analysis of Different District Heating Systems Aided by Geothermal Energy. Energies 2018, 11, 1265. [CrossRef]

33. Bonamente, E.; Aquino, A. Life-Cycle Assessment of an Innovative Ground-Source Heat Pump System with Upstream Thermal Storage. Energies 2017, 10, 1854. [CrossRef]

34. Calise, F.; Capuano, D.; Vanoli, L. Dynamic Simulation and Exergo-Economic Optimization of a Hybrid Solar-Geothermal Cogeneration Plant. Energies 2015, 8, 2606-2646. [CrossRef]

35. Patsialis, T.; Kougias, J.; Kazakis, N.; Theodossiou, N.; Droege, P. Supporting Renewables' Penetration in Remote Areas through the Transformation of Non-Powered Dams. Energies 2016, 9, 1054. [CrossRef]

36. Alam, M.; Bhattacharyya, S. Decentralized Renewable Hybrid Mini-Grids for Sustainable Electrification of the Off-Grid Coastal Areas of Bangladesh. Energies 2016, 9, 268. [CrossRef]

37. Franzitta, V.; Curto, D.; Milone, D.; Rao, D. Assessment of Renewable Sources for the Energy Consumption in Malta in the Mediterranean Sea. Energies 2016, 9, 1034. [CrossRef]

(C) 2018 by the authors. Licensee MDPI, Basel, Switzerland. This article is an open access article distributed under the terms and conditions of the Creative Commons Attribution (CC BY) license (http:/ / creativecommons.org/licenses/by/4.0/). 